Portland State University

PDXScholar

7-31-1996

\title{
The Effectiveness of a Self-directed Inservice Program to Educate Teachers about the Classroom Needs of Students with Hearing Impairment
}

Teresa Michelle Whiteley

Portland State University

Follow this and additional works at: https://pdxscholar.library.pdx.edu/open_access_etds

Part of the Speech and Rhetorical Studies Commons

Let us know how access to this document benefits you.

\section{Recommended Citation}

Whiteley, Teresa Michelle, "The Effectiveness of a Self-directed Inservice Program to Educate Teachers about the Classroom Needs of Students with Hearing Impairment" (1996). Dissertations and Theses. Paper 5141.

https://doi.org/10.15760/etd.6991

This Thesis is brought to you for free and open access. It has been accepted for inclusion in Dissertations and Theses by an authorized administrator of PDXScholar. Please contact us if we can make this document more accessible: pdxscholar@pdx.edu. 


\section{THESIS APPROVAL}

The abstract and thesis of Teresa Michelle Whiteley for the Master of Science in Speech Communication: Speech and Hearing Science were presented July 31, 1996, and accepted by the thesis committee and the department.

COMMTTTEE APPROVALS:
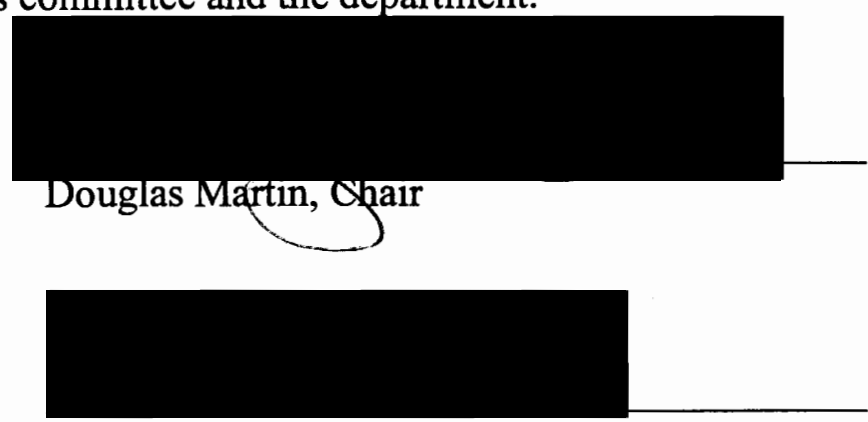

Rhea Paul

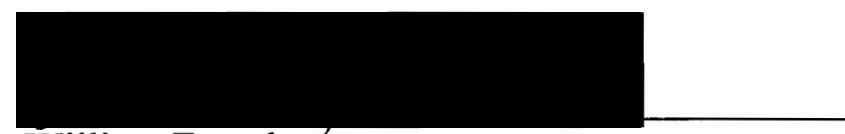

William Feyerherm

Representative of the Office of Graduate Studies

DEPARTMENT APPROVAL:

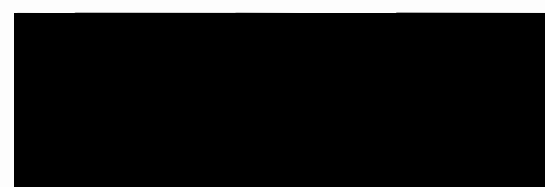

Rhea Paul, Acting Chair

Department of Speech Communication

ACCEPTED FOR PORTLAND STATE UNIVERSITY BY THE LIBRARY

by

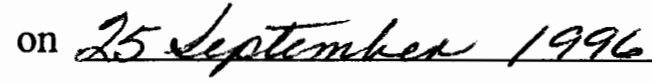




\begin{abstract}
An abstract of the thesis of Teresa Michelle Whiteley for the Master of Science in Speech Communication: Speech and Hearing Science presented July 31, 1996.
\end{abstract}

Title: The Effectiveness of a Self-Directed Inservice Program to Educate Teachers About the Classroom Needs of Students with Hearing Impairment.

Students with mild to moderate hearing losses, and some with severe hearing losses, are mainstreamed in a regular classroom for all or part of the day (Martin, Berstein, Daly \& Cody, 1988). While these students may require special education services, the classroom teacher plays a vital role in the overall education and daily management of a child with a hearing impairment (Hass, 1987). Villa (1989) reported that many school employees have not received adequate training to educate these students. Therefore, it becomes the school's responsibility to educate teachers through a comprehensive inservice training program.

One format for providing such a program is a self-directed inservice program. This approach can be utilized as a cost-effective means of meeting the professional needs of educators, although little is known regarding its' effectiveness to train teachers about the needs of students with hearing impairments. 
To address the effectiveness of a self-directed inservice approach, a comprehensive self-directed inservice program which provides information about hearing loss, behavior manifestations of children with hearing impairment, hearing aid maintenance, and mainstreaming was developed. This program was designed to educate teachers about the classroom needs of students with hearing impairment. A group of 20 teachers were randomly assigned to either the experimental group, which received the inservice program or control group, who read a brief article. A post test was administered to both groups, and the experimental group also answered a questionnaire regarding the inservice program.

The results revealed a significant difference in the basic knowledge of regular education teachers about the classroom needs of students with hearing impairments for those receiving the program. This suggests that a self-directed inservice program is a viable method of educating teachers about the needs of students with hearing impairments. 
THE EFFECTIVENESS OF A SELF-DIRECTED INSERVICE PROGRAM TO EDUCATE TEACHERS ABOUT THE CLASSROOM NEEDS OF STUDENTS WITH HEARING IMPAIRMENT

by

TERESA MICHELLE WHITELEY

A thesis submitted in partial fulfillment of the requirements for the degree of

MASTER OF SCIENCE

in

SPEECH COMMUNICATION:

SPEECH AND HEARING SCIENCE

PORTLAND STATE UNIVERSITY

1996 


\section{ACKNOWLEDGEMENTS}

I would like to give my deepest thanks to Doug Martin, my thesis advisor, for his initial interest in this project. His help and encouragement enabled me complete this thesis by the time I finished my graduate program.

Thank you to other committee members, Rhea Paul and Bill Feyerherm, for their helpful comments and guidance.

I would also like to thank my parents for their constant love, prayers, and encouragement to complete not only this thesis, but anything I set out to accomplish in life.

Finally, I dedicate this work to my husband, Tim. Each step of the way he provided me with love, support, encouragement, and prayers. He endured a lot of "fast food" and many late nights of studying so I could complete this thesis and obtain my degree.

I am confident that none of this would have been possible were it not for the grace of the Lord and His goodness. "Delight thyself also in the Lord; and he shall give thee the desires of thine heart" (Psalm 47:4). 


\section{TABLE OF CONTENTS}

PAGE

ACKNOWLEDGEMENTS ….............................................................. iii

LIST OF TABLES ……………………..................................................... vii

CHAPTER

I INTRODUCTION AND STATEMENT OF PURPOSE.............1

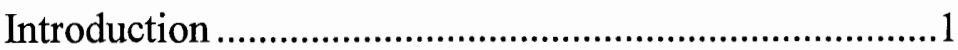

Statement of Purpose......................................................

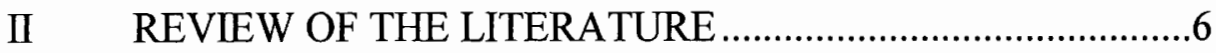

The Effects of Hearing Loss on Child Development ......6

Speech

Listening

Language

Academic Achievement

Social Behavior

Indications of the Need for Teacher Inservice on

Hearing Impairment ..................................................10

Inservice Training …….................................................13

Self-Directed Inservice Training .....................................14

Components of a Teacher Inservice on Hearing

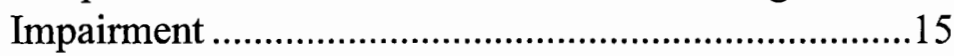

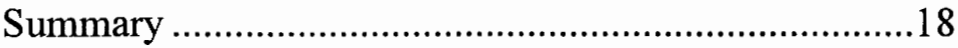




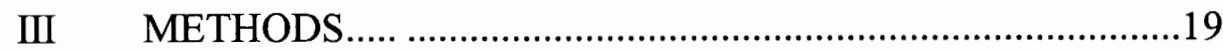

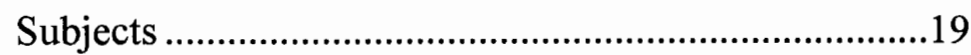

Self-Directed Inservice Program ..................................21

Examination Instrument ...........................................22

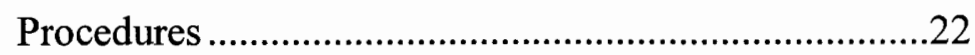

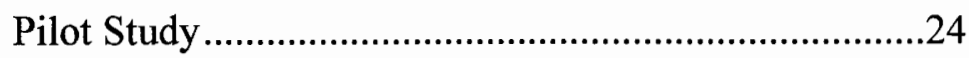

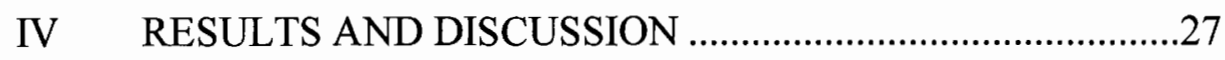

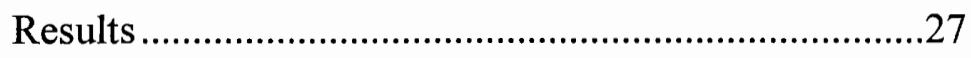

Implications of a Hearing Impairment

Behavior Manifestations of a Child with a

Hearing Impairment

Hearing Aids

Helping the Student with a Hearing Impairment in the Classroom

Untrained Questions

Questionnaire

Discussion

V SUMMARY AND IMPLICATIONS

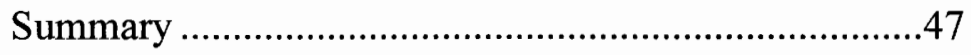

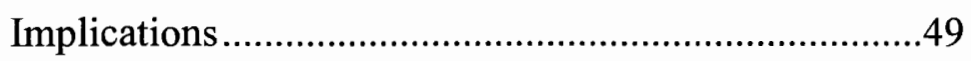

Clinical Implications

Research Implications 
APPENDICES

A RECRUITMENT LETTER ...............................................57

B INFORMED CONSENT LETTER..................................59

C SURVEY OF TEACHER'S EXPERIENCE AND

KNOWLEDGE OF HEARING IMPAIRMENT ...............61

D SELF-DIRECTED INSERVICE PROGRAM ......................64

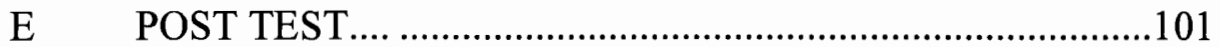

F SELF-DIRECTED INSERVICE PROGRAM FEEDBACK..106

G ARTICLE READ BY CONTROL GROUP ......................108

H SELF-DIRECTED INSERVICE PROGRAM

FEEDBACK RESPONSES 110 


\section{LIST OF TABLES}

Summary of Group Performance on Implications of a

Hearing Impairment

Summary of Group Performance on Behavior Manifestations of a Child with Hearing Impairment .32

V

Summary of Group Performance on Hearing Aids .35 Summary of Group Performance on Helping the Student with a Hearing Impairment in the Classroom .37 


\section{CHAPTER I}

\section{INTRODUCTION AND STATEMENT OF PURPOSE}

\section{Introduction}

Education is essential in the life of a child. The expansion of knowledge, development of social skills, and enhancement of language abilities lay the foundation for future academic and vocational success. As an extension of this objective, the passage of Public Law 94-142, the Individuals with Disabilities Education Act (IDEA), mandates that all children receive a free and appropriate public education, regardless of disability. Hearing loss is one of many disabilities covered under IDEA. Ross (1978) reported the prevalence rate of children with hearing loss is approximately 30 per 1000 school children.

A hearing impairment, even when mild, can disrupt a child's languagelearning process and interfere with his or her development (Flexer, 1994). According to Berg, Blair, Viehweg, and Wilson-Vlotman (1986), children with hearing impairment often experience listening problems and delayed speech development. Since children with hearing loss receive less sound input during the formative years of life, language learning opportunities are reduced. While differing language abilities may be expected, Schow and Nerbonne (1989) point 
out that phonology, syntax, morphology, and pragmatics are typically delayed in children with hearing impairment:

Listening, speech, and language deficits affect the cognitive development of the hearing impaired child and may impede academic success (Berg et al., 1986). In studies of children with mild and moderate hearing impairment, Blair, Peterson, and Viehweg (1985) and Davis, Elfenbein, Schum, and Bentler (1986) found that even minimal hearing loss places students at risk for academic delay. Children with hearing impairment also experience a higher rate of emotional and social problems than their normal hearing peers (Berg et al., 1986). Davis, Elfenbein, Schum, and Bentler (1986), indicated that fifty percent of the children with hearing impairment in their study experienced teasing from other children and reported difficulty making friends.

Public education plays a major role in the lives of children. Given all of the above effects of a hearing loss, it is important to recognize that it is the responsibility of the school system to provide the special assistance necessary for educating children with hearing impairment (Martin, Bernstein, Daly, \& Cody, 1988). Audiological services for children aged 3 to 21 , including hearing management, is supported by federal law through the establishment of the Individualized Family Service Plan (IFSP) and the Individualized Education Plan (IEP). These two documents serve as the "educational framework that will be used 
to teach the child for the remainder of his or her school career" (Flexer, 1994, p. $155)$.

Children with hearing impairment have special needs that may require the services of a speech-language pathologist. educational audiologist, or teacher of the hearing impaired. However, students with mild to moderate hearing losses, and some with severe hearing losses, will be mainstreamed in a regular classroom for all or part of the day (Martin, Bernstein, Daly, \& Cody, 1988). Oyer, Crowe, and Hass (1987) emphasized that the importance of the classroom teacher in the overall education and daily management of a child with a hearing impairment cannot be underestimated. They indicated the necessity that classroom teachers have a general understanding of the nature of hearing loss as well as the social, communication, and educational problems manifested by the loss. Not all teachers, however, possess the knowledge for meeting the classroom needs of children with hearing impairment (Martin et al., 1988). Osborne and Dimattia (1994) reported that classroom teachers in many school districts have not been properly trained to provide meaningful instruction to students with a variety of disabilities.

One way to educate teachers about these issues is through inservice training (Beaver, Hayes, \& Luetke-Stahlman, 1995). Villa (1989) reports that many school employees have not received adequate training to educate all their students in the mainstream of the regular classroom. Therefore, it becomes the job of those responsible for planning inservice for the local school to implement a 
comprehensive inservice training program. While inservice has been shown to benefit teachers, Fitch (1982) and Luckner (1991) found that little information was provided to general education teachers concerning deaf and hearing impaired students.

A common means of providing inservice training has been a lecture/discussion workshop. However, given the time constraints of classroom teachers due to large class sizes and increased work loads, this may not be the best method to educate today's teachers about the classroom needs of students with hearing impairment. Lass et al. (1986) suggested several possible formats for presenting information on hearing loss to professionals. One method is a selfdirected inservice program containing information and examination questions. Friedman, Lehrer, and Stevens (1983) indicated that a self-directed program can be utilized as a cost-effective means of meeting the professional needs of educators. Another advantage to this type of training is that it can be completed at the teacher's own pace.

\section{Statement of Purpose}

The purpose of this study is to determine whether a self-directed inservice program which provides information about hearing loss, behavior manifestations of children with hearing impairment, hearing aid maintenance, and mainstreaming will effect a change in the basic knowledge of regular education teachers regarding the 
classroom needs of students with hearing impairment. Specifically, this study proposes to formulate and administer a self-directed inservice program to regular education teachers and then to measure the impact of the inservice through the use of a written examination. This study seeks to answer the following research question: Will a comprehensive self-directed inservice program effect a change in the basic knowledge of regular education teachers regarding the classroom needs of students with hearing impairment? 


\section{CHAPTER II}

\section{REVIEW OF THE LITERATURE}

The literature review begins with a description of the effects of hearing loss on speech, language, listening, academic achievement, and social behavior. These issues will be discussed regarding their probable effects on educational performance, followed by a rationale for the need for teacher inservice on hearing impairment. The role of inservice training in an educational setting will be discussed, with a comparison of a traditional lecture/discussion inservice and a selfdirected inservice. The potential components of a teacher inservice on hearing impairment will be presented, followed by a summary of the aspects of the literature that this study will address.

\section{The Effects of Hearing Loss on Child Development}

\section{Speech}

Berg (1987) indicated that as the degree of hearing loss increases, the extent of the speech problem increases. A child who is hard of hearing will be delayed in speech development, while a child who is deaf will not learn to speak at all without special training (Berg, 1987). Trybus (as cited in Berg et al., 1986) reported that in 
a study of 978 children with hearing impairment, 90 percent of children with a hearing loss of $55 \mathrm{~dB}$ or less in the better ear were rated intelligible or very intelligible, whereas only 3 percent of children with hearing loss greater than $91 \mathrm{~dB}$ were rated very intelligible. Two phonologic analyses (Oller \& Kelly, 1974; West \& Weber, 1974) indicated that children with mild to moderate hearing losses produce speech errors comparable to that of younger normal-hearing peers.

\section{Listening}

Whenever a child exhibits any degree of hearing loss, a listening problem is also present (Berg, et. al, 1986). In particular, children have difficulty receiving speech. Speech reception can break down at various listening levels. These include detection, discrimination, identification, and comprehension. The authors go on to say that children with unilateral or bilateral hearing loss may also have problems listening in regular classrooms. The classroom noise level and reverberation time greatly influence the degree to which students can understand the teacher.

Maxon and Brackett (1987) reported that the extent of difficulty for children to understand speech is related to the range of acoustic cues that are audible to the child through amplification. The child's ability to take advantage of aided hearing will result in greater understanding of lecture material with little or no visual support. The authors further stated that while hearing loss varies in degree from 
mild to profound, the child's ability to use residual hearing is the critical factor for success.

\section{Language}

Children with a hearing impairment generally have deficient language skills (Berg, 1987). A degraded speech acoustic signal results in reduced input of information regarding the form (phonology, syntax, morphology), content (semantics), and use (pragmatics) of language (Schow and Nerbonne, 1989). Norlin and VanTasell (1980) indicated that language abilities cannot be predicted strictly on the severity of hearing loss, because of factors such as speechdiscrimination abilities, ability to use amplification, the individual child's ability to learn language, and the child's ability to tolerate and use incomplete data. Therefore, when presented with a limited auditory signal, some children may be able to understand the message and its context more easily.

Children with hearing impairment usually exhibit deficits in vocabulary comprehension, complex syntax, and understanding and using figurative language (Berg, 1986). Davis (1974) looked at results from a picture test of basic concepts and found that $75 \%$ of children with hearing losses from $25-70 \mathrm{~dB}$ in the better ear fell at or below the 10 th percentile, with approximately $66 \%$ scoring at the first percentile. Davis and Blasdell (1975) found that vocabulary deficits are often accompanied by a delay in complex syntactical development. The children in this 
study were unable to process and comprehend embedded phrases, nor were they able to keep up when a large number of grammatical transformations occurred in a single sentence.

\section{Academic Achievement}

The language deficit of hard-of-hearing children is a significant educational problem (Berg et al., 1986). Even minimal hearing loss in children during the early school years has a negative effect on general academic performance. In a landmark study by Quigley \& Thomure (as cited in Davis, 1977), children with a moderate hearing loss $(40-55 \mathrm{~dB})$ performed three years below their normally hearing peers in word meaning, paragraph meaning, and language ability on the Standard Achievement. Jensema (as cited in Berg et al., 1986) reported reduced scores on mathematical concepts and computation, along with depressed vocabulary and reading comprehension. Scores were increasingly lower as bilateral hearing loss increased from mild to profound.

Blair, Peterson, and Viehweg (1985) compared the academic performance of 24 children with a mild sensorineural hearing loss of 20 to $45 \mathrm{~dB}$ to a control group of 24 normal-hearing children. First, second, third, and fourth grade students with mild hearing losses were behind their normal hearing peers in arithmetic problem solving, math concepts, vocabulary, and reading comprehension. The academic gap between the student with a hearing impairment and the child with 
normal hearing suggests that academic difficulty may increase with age (Berg et al., 1986; Blair, Peterson, \& Viehweg, 1985).

\section{Social Behavior}

Many children with a hearing impairment often feel isolated, inadequate, and helpless (Berg, et al, 1986). Frequent speech misunderstanding can lead to withdrawal, acting out, talking too much, or other inappropriate compensatory reactions. Vernon (as cited in Berg et al., 1986) reported that many of these individuals may either remain quiet or try to dominate conversation to avoid having to understand what is being said. Antia (1985) found that children with hearing impairments who were linguistically proficient interacted more with their peers with normal hearing than children with low linguistic skills.

\section{Indications of the Need for Teacher Inservice on Hearing Impairments}

In 1975, P.L. 94-142, Congress passed the Education for All Handicapped Children Act, reauthorized as the Individuals with Disabilities Act (IDEA) in 1990. According to the law, "students with disabilities are to be provided with a free, appropriate public education in the least restrictive environment" (Osborne \& Dimattia, 1994,pg. 6). Federal guidelines mandate that each student have an Individualized Family Service Plan (IFSP) or Individualized Education Program (IEP) that specifies the student's individual needs in the setting that allows the 
greatest opportunity for interaction with students who do not have disabilities (Flexer, 1994). According to the US Department of Education 60,763 children with hearing impairments received special education services during the 1991-1992 school year (as cited in Holt, 1994). They further reported that almost one half (47\%) were mainstreamed into regular classes with hearing students, while 33\% were placed in separate classes within local schools, and $20 \%$ were in special schools.

It appears that increasing numbers of regular classroom teachers are faced with the responsibility of educating many of these students (Martin et. al, 1988). Previous research indicates that regular education teachers feel they have not been properly trained to educate students with hearing impairments (Fitch, 1982; Lass, Tecca, Woodford, 1987; Luckner, 1991; Martin et. al, 1988). Therefore, it is essential that teachers receive information about the classroom needs of these students (Martin et. al, 1988).

Martin and his colleagues (1988) administered an 84-item questionnaire to 187 classroom teachers to determine their knowledge about hearing impairments and their attitudes toward mainstreaming. Results revealed the sample population had a limited knowledge of hearing disorders and did not want to be responsible for checking hearing aids. The overall attitude about mainstreaming students with hearing impairments was positive; however, the majority of teachers indicated they would want support staff and additional training before teaching a child who has a 
hearing impairment. The authors suggested that this type of education be conducted through preservice training, inservice training, and continuing education classes.

Lass, Tecca, and Woodford (1987) surveyed 113 teachers to ascertain their knowledge, experience, and attitudes regarding hearing aids and individuals who wear hearing aids. Deficiencies were noted in these areas, indicating a need for training at the preservice and continuing education levels. Fitch (1982) also indicated the need to provide regular education personnel with training about hearing loss and the needs of children with hearing impairments. He further stated that for mainstreaming to be effective, teachers who have not had formal training in working with a child with hearing loss needs to be educated about the problem.

Luckner (1991) conducted a survey of 354 regular education teachers who currently had students with hearing loss in their class to determine their attitudes toward mainstreaming. While most teachers indicated positive attitudes, they also reported a lack of training on the effects of hearing loss on the student, as well as a lack of information regarding hearing aids. The author indicated that the education of students with hearing impairment is shared by both regular and special education teachers. As such, regular education teachers need additional training and assistance to accomplish this effectively. 


\section{Inservice Training}

Inservice education is a basic element on which teachers depend to extend their professional skills. Villa (1989) reported that many school employees have not received adequate training to educate all their students in the mainstream of the regular classroom. Therefore, it becomes the job of those responsible for planning inservice for the local school to implement a comprehensive inservice training program. Hendrickson, O’Shea, Gable, Heitman, and Sealander (1993), define inservice education as:

(a) a process through which educators maintain and update their knowledge and professional expertise;

(b) an opportunity to examine, to enhance, and to redefine professional responsibilities;

(c) a vehicle for establishing and evaluating educational goals;

(d) a mechanism for networking and for resource development; and

(e) a context for promoting self-assessment and job enhancement. (p. 31-32)

These authors believe the purpose of inservice education should be to plan programs which further the professionalism of teachers through learning opportunities to improve performance. They further indicate that inservice workshops continue to be the most common format for staff development.

Sparks and Loucks-Horsley (1989) indicated that most teachers are familiar with attending workshop-type sessions in which the instructor establishes the objectives, content, and flow of activities. A benefit of this traditional type of inservice is that the instructor can use a variety of activities to engage the 
participants (e.g., lecture, demonstration, role-playing, simulation, and microteaching) which will aid in achieving the desired outcomes.

\section{Self-Directed Inservice Training}

Lass and his colleagues (1986) suggested several possible formats for presenting information on hearing loss to professionals. One method was a selfdirected inservice program containing information and examination questions. Bynum and Rosenblatt (1984) define self instruction as "courses of study--workrelated training or self-improvement programs--in which learners are expected to master the material on their own, working without direct supervision, usually at their own pace" ( p. 61). In reviewing different types of self instruction training, the authors reported that most programs rely on audio- or videotapes, books, and manuals, often including some type of written examples and practice exercises.

Friedman, Lehrer, and Stevens (1983) conducted a study with 85 classroom teachers to determine the effectiveness of self-directed and lecture/discussion stress management approaches. The subjects were divided into two experimental groups and one control group. One experimental group received self-directed instruction and the other experimental group participated in a lecture/discussion. The material presented in both formats were the same. The results indicated that both types of instruction were effective in reducing stress; however the self-directed instruction was viewed as the most cost-effective method for school systems. 
Kelly and Vanvactor (1983) conducted a study to determine the cost effectiveness of alternative types of inservice programs that can be used in remote, rural schools. These approaches included training by: (a) independent study, (b) master teachers employed by the school district, (c) university instructors on university campus, and (d) university instructors at the school site. Cost effectiveness was based on knowledge gain and on-site utilization. The average cost of these inservice programs ranged from $\$ 22,260.00$ (independent study) to $\$ 28,965.00$ (training by university instructors on university campus). The 2-year results indicated that direct instruction yielded a higher knowledge gain than the self-directed approach. These authors concluded that while the independent study approach had lower overall costs, it proved less cost effective than the other methods due to the lower knowledge gain.

\section{Components of a Teacher Inservice on Hearing Impairment}

Davis, Shepard, Stelmachowicz, and Gorga (1981) made several suggestions for inservice training on hearing impairment based on the results of their study involving 874 returned questionnaires from various school personnel, (i.e., regular teachers, special education teachers, speech-language pathologist, teachers of the deaf, psychologists, and counselors). The survey contained questions about the respondents' experience with children with hearing impairments, problems encountered, attitudes, and suggestions for inservice 
training in hearing impairment. Results revealed a lack of knowledge regarding hearing aids, academic achievement, and curriculum modification. The authors concluded that inservice content should focus on at least four components: (a) characteristics of hearing loss, (b) characteristics of children being served, (c) knowledge of the service delivery system, and (d) perceptions, background, and training of the population receiving the inservice. The authors suggested that the inservice content will vary depending on the professionals receiving the training. According to Davis (1977), teacher inservices should help inform school faculty about the effects of hearing impairment and give suggestions concerning what can be done to aid students that present these difficulties. She suggested that the following topics be covered in an inservice on hearing impairment:

1. how to recognize signs of poor hearing,

2. the effects of noise on communication,

3. the advantages and limitations of hearing aids,

4. how to check hearing aids for malfunction,

5. how to use auditory training units effectively,

6. the language and academic effects of hearing loss

7. the characteristics of the hearing loss of the particular child to be served

8. the linguistic and educational status of the particular child to be served.

9. techniques for maximizing communication with hearing impaired,

10. the roles of specialists who are available for support and guidance. 
Fitch (1982) stressed the importance of inservice training on hearing loss for educational personnel. He believed an inservice on hearing loss should provide information to school personnel on the characteristics and needs of children with hearing impairment, along with recommendations for management strategies. Fitch recommended the use of the System ONE kit (as cited in Fitch, 1982), which contains a variety of filmstrips, in either a 5-hour workshop or 3-hour abbreviated presentation. The following topics from Fitch's inservice guidelines were used in the development of the self-directed inservice program used in this study: (a) hearing loss/anatomy of the ear, (b) hearing aids/amplification, (c) classroom management, and (d) academic skills.

Many of the suggestions made by Davis (1977) were also used in the development of the self-directed inservice program used in this study. Specifically, the program addressed the effects of noise on communication and the language and academic effects of hearing loss in the section on implications of a hearing impairment. The section on behavior manifestations discussed how to recognize signs that may indicate hearing loss. The advantages and limitations of hearing aids, along with guidelines on how to check hearing aids for malfunctions were covered in the hearing aid section of the inservice program. The last section of the program focused on helping the student with a hearing impairment in the mainstream classroom. Techniques for maximizing communication with hard-ofhearing children were presented along with other classroom management strategies. 
The program used in this study was based on the ideas that Fitch (1982) and Davis (1977) believed to be important for teachers to know regarding students with hearing impairment.

\section{$\underline{\text { Summarv }}$}

With all of the above research on hearing impairment, one can conclude that the effects of hearing loss on speech, language, listening, academic achievement, and social behavior adversely affect the development and education of a child with a hearing impairment. Realizing that students with hearing impairments have special needs, regular education teachers must be ready to meet those needs for children who are mainstreamed into their class. The literature revealed that teachers are not properly trained, therefore, it is the schools' responsibility to educate teachers through inservice (Villa, 1989). A lecture/discussion workshop has been a common means of furthering the education of teachers. This study proposes to provide inservice training through a self-directed approach such as the one advocated by Lass and his colleagues (1986). 


\section{CHAPTER III}

\section{METHODS}

The goal of this study was to determine whether a self-directed inservice program which provides information about hearing loss, behavior manifestations of children with hearing impairment, hearing aid maintenance, and mainstreaming would effect a change in the basic knowledge of regular education teachers regarding the classroom needs of students with hearing impairment. Specifically, this study proposed to formulate and administer a self-directed inservice program to regular education teachers and then to measure the impact of the inservice through the use of a written examination.

\section{$\underline{\text { Subjects }}$}

The prospective pool of subjects were recruited by sending letters about the study (Appendix A) to the principals of various elementary schools in the Portland, Oregon and Vancouver, Washington metropolitan area. The principals were asked to post the letter and/or ask for volunteers who were interested in participating in the study. Approximately one week after the letters were mailed, the principals were contacted by phone to answer any questions regarding the study and to obtain 
a list of teachers interested in serving as subjects in the study. This yielded 23 consenting subjects (Appendix B) from various schools who were contacted by phone and asked to complete a survey (Appendix C) regarding their experience and knowledge of hearing impairment. Selection criteria for participation in the study required that each subject have at least three years teaching experience in K-6 grades. The group was reduced to 20 subjects who met the selection criteria. The total years of teaching experience by the 20 subjects ranged from 4 to 30 years, with a mean of 13.25 years. None of the subjects reported having a diagnosed hearing impairment; however, one subject believed she might have a slight hearing loss. Five subjects indicated having a parent or grandparent with a hearing impairment and two subjects reported having a child with a hearing impairment; however, none of the parents or children wore hearing aids or received any special services. More than half of the subjects (11) knew a child with a hearing impairment. Fourteen of the 20 subjects had taught a student with a hearing impairment during their teaching career. In response to the question regarding previous training in hearing impairment, two of the subjects indicated having taken a sign language course and one subject recalled hearing loss being mentioned in a class she took on exceptional children 20 years ago. 


\section{Self-Directed Inservice Program}

An outline of self-directed inservice program that was used in this study is provided in Appendix D. The topics covered in the inservice program were based on suggestions that Fitch (1982) and Davis (1977) believed were important for teachers to know regarding students with hearing impairment. These included implications of a hearing impairment, behavior manifestations of children with hearing impairment, hearing aids, and mainstreaming. The actual contents of the inservice program were gleaned from a variety of sources, including Davis (1977), Fisher (1976), Flexer (1994), Roeser and Downs (1981), Simko (1986), and Wayner (1990). There was a set of self-assessment questions, with answers provided on the subsequent page, at the end of each topical section that addressed the key points in the section.

The first section was on implications of a hearing impairment. It discussed basic anatomy of the ear, real-world implications of what a hearing loss means, and the educational considerations and special needs of students with a hearing impairment. The section on behavior manifestations addressed signs that may indicate hearing loss, along with various checklists that teachers can use if they suspect a student may be experiencing difficulty hearing. A section was also be included on hearing aids. It contained information about audiograms, different kinds of hearing aids, a hearing aid checklist to determine if the aid is working 
properly, and tips for troubleshooting a student's hearing aid. The last section was on classroom issues. It consisted of concerns of the regular education teacher, ideas for helping students with hearing impairments in the regular classroom, and gestures and facial expressions that can be used in the classroom.

\section{Examination Instrument}

The post test that was administered to the subjects is included in Appendix E. It was used to measure the subjects' knowledge about hearing and the classroom needs of children with hearing impairment. The test consisted of 21 objective questions that coincided with the information provided in the inservice program along with 4 objective questions that served as untrained items.

\section{Procedures}

An independent group design was used for this study. Subjects were randomly assigned to two groups, the experimental group and the control group. The experimental group $(n=10)$, was given the self-directed inservice program. These subjects were given one week to complete the self-directed inservice program. At the end of this one-week period, a post-test was administered at their respective schools by the researcher. However. a speech-language pathologist administered the post test to one of the subjects due to the location of the subject's school. After the post test was given to the researcher, the subject was asked to 
provide written feedback about the inservice program (Appendix F). The following written instructions were given to the subjects in the experimental group:

You have been given a booklet entitled "Meeting the Classroom Needs of Students with Hearing Impairment." This is a self-directed inservice program which provides information about hearing loss, behavior manifestations of children with hearing impairment, hearing aid maintenance, and mainstreaming. You should start at the beginning of the booklet and work to the end. There will be a set of self-assessment questions at the end of each section that address the key points in that section. The answers to these questions are provided in the booklet; however, you are encouraged to answer each question prior to reviewing the answer. You will be given one week to complete the inservice program. At the end of the week, you will be asked to complete a post test and provide written feedback about the inservice program. Please do not discuss the contents of the inservice program with other participants until the completion of the study.

The subjects in the control group $(\mathrm{n}=10)$, were given a short article to read entitled, "Deaf Culture," ("Let's Talk," 1995). This article is provided in Appendix G. These participants were given one week to read the article. At the end of this one-week period, a the same post test that the experimental group received was administered at their respective schools by the researcher. The following written instructions were given to the subjects in the control group:

You have been given a brief article to read. You will be given one week to read the article. At the end of the week, you will be asked to complete a post test. Please do not discuss the contents with other participants until the completion of the study.

At the end of the one week period both groups were given the post test. The following instructions were given at the time of testing: 
You have each been given a post test. Please circle the option which best answers the question. When you are finished, please turn in your test to me. Do you have any questions?

\section{Pilot Study}

A pilot study was conducted at Portland State University with a group of 10 undergraduate students in the speech-language pathology program. The purpose of the pilot study was to evaluate the program's ability to convey new information as well as to assess the potential use of the self-assessment questions as a post test. The self-directed inservice program was administered to five students. The selfassessment questions were given to both the group who received the inservice program and the group who did not have access to the information.

Due to these students' academic experiences, it was anticipated that there would not be a difference on self-assessment answers regarding hearing loss and mainstreaming. This proved true, as there was not a notable difference in the answers given regarding those issues in either group. As expected, differences did exist between the two groups in areas relative to hearing aids and behavior manifestations of children with hearing impairment, topics in which the students had not received prior training. The group that completed the self-directed inservice program performed better on self-assessment questions regarding these areas than those who did not complete the inservice program. 
Specifically, in response to the question, "Fill in the correct solutions for a 'dead' hearing aid in which there is no sound," four out of five students who read the packet provided the correct answer, while only one out of five students who did not read the packet answered the question correctly. There were nine causes and solutions for a "dead" hearing aid. Correct solutions included the following: replace the battery, clean the tubing, adjust the controls, etc. Incorrect answers from those who did not read the packet included the following: buy new tubing, go to the audiologist where hearing aid was purchased, and test the controls on a charger. Two of the students who did not read the packet did not attempt to answer the question.

In response to the question, "When should a teacher use Fisher's Auditory Problems Checklist?" all of the students who read the packet correctly stated that it should be used when a teacher suspects a child has a hearing loss. One of the students who did not read the packet answered this question correctly; however, four of the students who did not read the packet did not attempt to answer the question.

These findings were consistent with the hypothesis that both groups would perform well on examination questions regarding areas previously covered in there classes, while the group who completed the inservice program would perform well on all examination questions. The use of the self-assessment questions as a post 
test was rejected in favor of an objective, multiple choice format to avoid potential difficulties in obtaining inter-judge reliability. 


\section{CHAPTER IV}

\section{RESULTS AND DISCUSSION}

\section{$\underline{\text { Results }}$}

The data collected were analyzed using both descriptive and inferential statistics. A subjective item-by-item analysis was constructed to determine areas of strength and weakness in the program and/or post test. The 25 post test items were grouped into five categories regarding the information covered in the self-directed inservice program along with a set of untrained questions. These five categories consisted of: implications of a hearing impairment, behavior manifestations of a child with a hearing impairment, hearing aids, helping the student with a hearing impairment in the regular classroom, and untrained questions.

Descriptive statistics for the experimental group revealed a mean score of $70.0 \%$ with a standard deviation of 11.7 (See Table I). The minimum and maximum scores were $48 \%$ and $88 \%$, respectively. The control group had a mean score of $56.4 \%$ and a standard deviation of 9.7 . The minimum and maximum scores were $36 \%$ and $72 \%$, respectively. The performance of both groups on all test 
items of the post test were compared using a two-tailed t-test. Results indicated a significant difference between the two groups $(\mathrm{t}=-2.58 ; \mathrm{p}=0.02)$.

The performance of each group was also compared with the untrained test items on the post test excluded from analysis (See Table II). Descriptive statistics for the experimental group revealed a mean score of $74.3 \%$ with a standard deviation of 12.1 . The minimum and maximum scores were $52.4 \%$ and $90.5 \%$, respectively. The control group had a mean score of $55.7 \%$ and a standard deviation of 9.8 . The minimum and maximum scores were $38.1 \%$ and $71.4 \%$, respectively. A two-tailed t-test continued to reveal a significant difference between the two groups $(\mathrm{t}=-3.84 ; \mathrm{p}=.001)$. 
TABLE I

SUMMARY OF GROUP PERFORMANCE ON ALL TEST ITEMS

\begin{tabular}{|l|c|c|}
\hline Descriptive Statistics & Experimental Group & Control Group \\
\hline Mean & $70.0 \%$ & $56.4 \%$ \\
\hline Standard Deviation & 11.7 & 9.7 \\
\hline Minimum Score & $48 \%$ & $36 \%$ \\
\hline Maximum Score & $88 \%$ & $72 \%$ \\
\hline
\end{tabular}

TABLE II

SUMMARY OF GROUP PERFORMANCE ON TRAINED TEST ITEMS ONLY

\begin{tabular}{|l|c|c|}
\hline Descriptive Statistics & Experimental Group & Control Group \\
\hline Mean & $74.3 \%$ & $55.7 \%$ \\
\hline Standard Deviation & 12.1 & 9.8 \\
\hline Minimum Score & $52.4 \%$ & $38.1 \%$ \\
\hline Maximum Score & $90.5 \%$ & $71.4 \%$ \\
\hline
\end{tabular}




\section{Implications of a Hearing Impairment}

The responses of the subjects from both groups about the implications of a hearing impairment were similar on three of the six items (See Table III). Over $90 \%$ of both groups correctly answered questions pertaining to a breakdown in communication, what happens when sounds hit the ear drum, and the location of the nerve ending responsible for hearing. There was a thirty percentage point difference in the performance between both groups (100\% Experimental Group and $70 \%$ Control Group) regarding which three bones are found in the middle ear. None of the subjects in the control group knew the name for the part of the outer ear we see on the side of the head (i.e., pinna), while all members of the experimental group answered it correctly.

\section{Behavior Manifestations of a Child with a Hearing Impairment}

The data for the questions related to behavior manifestations are provided in Table IV. For questions pertaining to indicators of hearing loss and uses of Fisher's Auditory Problems Checklist, $80 \%$ of both groups responded correctly. The question regarding problems that a student with a hearing impairment would not encounter in school was answered correctly by $70 \%$ of the experimental group and only $40 \%$ of the control group. 
TABLE 111

SUMMARY OF GROUP PERFORMANCE ON IMPLICATIONS

OF A HEARING IMPAIRMENT

\begin{tabular}{|c|c|c|}
\hline Question & $\begin{array}{c}\text { Experimental } \\
\text { Group } \\
\text { Percent Correct }\end{array}$ & $\begin{array}{c}\text { Control } \\
\text { Group } \\
\text { Percent Correct }\end{array}$ \\
\hline $\begin{array}{l}\text { 2. A breakdown in communication between two people } \\
\text { can cause: } \\
\text { a. anticipation } \\
\text { b. deliberation } \\
\text { c. frustration } \\
\text { d. palpitation }\end{array}$ & $100 \%$ & $100 \%$ \\
\hline $\begin{array}{l}\text { 8. The proper name for the part of the outer ear we see } \\
\text { on the side of the head is: } \\
\text { a. ossicle } \\
\text { b. cochlea } \\
\text { c. pinna } \\
\text { d. lobe }\end{array}$ & $80 \%$ & $0 \%$ \\
\hline $\begin{array}{l}\text { 11. What happens when sounds hit the eardrum? } \\
\text { a. The eardrum reverberates. } \\
\text { b. The eardrum vibrates. } \\
\text { c. The listener experiences pain. } \\
\text { d. All of the above }\end{array}$ & $90 \%$ & $90 \%$ \\
\hline $\begin{array}{l}\text { 14. The middle ear contains which three bones? } \\
\text { a. hammer, chisel, and bridle } \\
\text { b. hammer, anvil, and bridle } \\
\text { c. ratchet, anvil, and stirrup } \\
\text { d. hammer, anvil, and stirrup }\end{array}$ & $100 \%$ & $70 \%$ \\
\hline $\begin{array}{l}\text { 15. The nerve endings responsible for hearing are } \\
\text { found in which part of the ear? } \\
\text { a. the outer ear } \\
\text { b. the middle ear } \\
\text { c. the inner ear }\end{array}$ & $100 \%$ & $90 \%$ \\
\hline
\end{tabular}


TABLE IV

SUMMARY OF GROUP PERFORMANCE ON BEHAVIOR MANIFESTATIONS

OF A CHILD WITH HEARING IMPAIRMENT

\begin{tabular}{|c|c|c|}
\hline Question & $\begin{array}{c}\text { Experimental } \\
\text { Group } \\
\text { Percent Correct }\end{array}$ & $\begin{array}{c}\text { Control } \\
\text { Group } \\
\text { Percent Correct }\end{array}$ \\
\hline $\begin{array}{l}\text { 6. Which of the following is not a behavior that may } \\
\text { indicate hearing loss? } \\
\text { a. high achievement levels in classroom } \\
\text { studies } \\
\text { b. watches and concentrates on teacher's lips } \\
\text { c. talks too loudly or softly } \\
\text { d. shows strain in trying to hear }\end{array}$ & $100 \%$ & $80 \%$ \\
\hline $\begin{array}{l}\text { 12. When should a teacher use the Fisher's Auditory } \\
\text { Problems Checklist? } \\
\text { a. at the beginning of the school year on all } \\
\text { students } \\
\text { b. mid-year on all suspected hearing-impaired } \\
\text { students } \\
\text { c. prior to promotion to the next grade for all } \\
\text { students } \\
\text { d. as soon as hearing loss behaviors are } \\
\text { observed }\end{array}$ & $100 \%$ & $80 \%$ \\
\hline $\begin{array}{l}\text { 19. Which of the following is not an indication of a } \\
\text { hearing loss? } \\
\text { a. noncompliant behavior } \\
\text { b. prefers loud volumes } \\
\text { c. talks softly } \\
\text { d. turns one side of head toward speaker } \\
\text { e. these are all indications of a hearing loss }\end{array}$ & $100 \%$ & $90 \%$ \\
\hline $\begin{array}{l}\text { 25. Which of the following is not a problem that a } \\
\text { student with a hearing impairment might encounter in } \\
\text { school? } \\
\text { a. reading and spelling } \\
\text { b. trouble hearing films in school } \\
\text { c. difficulty in understanding directions } \\
\text { d. trouble watching films in sclool }\end{array}$ & $70 \%$ & $40 \%$ \\
\hline
\end{tabular}




\section{Hearing Aids}

Table V contains the data pertaining to the section on hearing aids. Subjects in the experimental group correctly answered more questions pertaining to audiograms, types of hearing aids, types of hearing loss, and expected benefits of hearing aids than the control group. When asked about the type of information that can be derived from an audiogram (questions \#3 and \#21), the experimental group correctly answered the question with $60 \%$ and $80 \%$ accuracy, respectively, while the control group scored $0 \%$ and $50 \%$, respectively. Ninety percent of the experimental group knew that an in-front-of-the ear hearing aid was not a true type of hearing aid, but no one in the control group responded correctly. More subjects in the experimental group correctly answered question \#13 regarding an expected benefit of wearing a hearing aid (60\% Experimental Group and 0\% Control Group). In response to the question regarding the three types of hearing loss, $70 \%$ of the experimental group answered correctly and $60 \%$ of the control group responded correctly.

Only $30 \%$ of both groups knew that a hearing aid may whistle if the earmold fits loosely. Ninety percent of both groups were able to identify situations that could result from a dead or weak battery. Subjects in the control group correctly answered questions $\# 7$ and $\# 9$ more often than the experimental group. Eighty percent of the control group knew that the term used to describe the whistling sound sometimes made by hearing aids is feedback, compared with $50 \%$ 
of the experimental group. Seventy percent of the control group and $30 \%$ of the experimental group knew the function of the receiver in a hearing aid.

\section{Helping the Student with a Hearing Impairment in the Classroom}

The responses given by both groups about the questions related to helping the student with a hearing impairment in the classroom were similar (See Table VI). Eighty percent of the experimental group knew how to get the attention of a child with a hearing impairment, compared with $60 \%$ of the control group. One of the subjects in the experimental group marked two answers for this first question, therefore, it was necessary to mark it incorrect. Only one subject from each group responded correctly to the accuracy of the following statement: "Displaying a positive attitude about hearing impairment and the child displaying difficulties can be a model for others in the class." The last question in this section asked for a behavior that would not encourage speech and language development or reinforce communicative effort. Of the 10 in each group 7 from the experimental group $(70 \%)$ answered correctly, while 8 from the control group (80\%) answered correctly. 
TABLE V

SUMMARY OF GROUP PERFORMANCE ON HEARING AIDS

\begin{tabular}{|c|c|c|}
\hline Question & $\begin{array}{c}\text { Experimental } \\
\text { Group } \\
\text { Percent Correct } \\
\end{array}$ & $\begin{array}{c}\text { Control } \\
\text { Group } \\
\text { Percent Correct } \\
\end{array}$ \\
\hline $\begin{array}{l}\text { 3. Which is not one of the types of information that can } \\
\text { be derived regarding a person's hearing loss from an } \\
\text { audiogram? } \\
\text { a. percent of hearing loss } \\
\text { b. pattern of hearing loss } \\
\text { c. degree of hearing loss } \\
\text { d. type of hearing loss }\end{array}$ & $60 \%$ & $0 \%$ \\
\hline $\begin{array}{l}\text { 7. The term used to describe the whistling sound } \\
\text { sometimes made by hearing aids is: } \\
\text { a. distortion } \\
\text { b. gain } \\
\text { c. feedback } \\
\text { d. output } \\
\text { e. amplification }\end{array}$ & $50 \%$ & $80 \%$ \\
\hline $\begin{array}{l}\text { 9. Which hearing aid component is responsible for } \\
\text { converting the amplified electrical signal back into } \\
\text { sound and delivering it to the child's ear? } \\
\text { a. microphone } \\
\text { b. amplifier } \\
\text { c. receiver } \\
\text { d. earmold } \\
\text { e. speaker }\end{array}$ & $30 \%$ & $70 \%$ \\
\hline $\begin{array}{l}\text { 13. Which of the following is an expected benefit of } \\
\text { wearing a hearing aid? } \\
\text { a. Hearing will be corrected in much the same } \\
\text { way that glasses correct vision. } \\
\text { b. Speech will be louder and easier to } \\
\text { understand. } \\
\text { c. The incidence of ear infections will } \\
\text { decrease. } \\
\text { d. All of these are expected benefits. } \\
\text { e. Only a or b can be expected to occur. }\end{array}$ & $60 \%$ & $0 \%$ \\
\hline $\begin{array}{l}\text { 16. Which of the following is not a type of hearing aid? } \\
\text { a. in front-of-the ear hearing aid } \\
\text { b. in-the-ear hearing aid } \\
\text { c. body hearing aid } \\
\text { d. none of these are hearing aid types } \\
\text { e. all of these are hearing aid types }\end{array}$ & $90 \%$ & $0 \%$ \\
\hline
\end{tabular}


TABLE V (CONTINUED)

SUMMARY OF GROUP PERFORMANCE ON HEARING AIDS

17. What arc the three types of hearing loss?

a. conductive, convective, sensorineural

b. mixed, convective, sensorineural

c. mixed, conductive, convective

d. mixed, conductive, sensorineural

20. A hearing aid may whistle if

a. the earmold fits loosely

b. the battery is weak or dead

c. the child speaks loudly

d. the hearing aid is old

e. the earmold is dirty or partially filled with wax

21. What type of information can be derived from an audiogram regarding a child's hearing loss?

a. the type and degree of loss

b. the percentage of words that a person can understand

c. whether surgery can be used to correct the hearing problem

d. the most appropriate classroom placement for a hearing-impaired child.

23. Which of the following situations could result from a dead or weak battery?

a. no sound from the hearing aid at all

b. intermittent sound from the hearing aid

c. poor sound quality from the hearing aid

d. all of these

e. only a or b 
TABLE VI

SUMMARY OF GROUP PERFORMANCE ON HELPING THE STUDENT

WITH A HEARING IMPAIRMENT IN THE CLASSROOM

\begin{tabular}{|c|c|c|}
\hline Question & $\begin{array}{l}\text { Experimental } \\
\text { Group } \\
\text { Percent Correct }\end{array}$ & $\begin{array}{c}\text { Control } \\
\text { Group } \\
\text { Percent Correct }\end{array}$ \\
\hline $\begin{array}{l}\text { 1. Which behavior is recommended if you want the } \\
\text { attention of a child with a hearing impairment? } \\
\text { a. stand in a dimly lit area so as to raise } \\
\text { curiosity } \\
\text { b. obscure your mouth or chew food while } \\
\text { speaking } \\
\text { c. be sure a light source is behind you when } \\
\text { giving instructions } \\
\text { d. kneel down to their level and look into } \\
\text { their eyes } \\
\text { e. none of these are recommended behaviors }\end{array}$ & $80 \%$ & $60 \%$ \\
\hline $\begin{array}{l}\text { 5. Displaying a positive attitude about hearing } \\
\text { impairment and the child displaying difficulties can be a } \\
\text { model for others in the class. } \\
\text { a. True } \\
\text { b. False }\end{array}$ & $10 \%$ & $10 \%$ \\
\hline $\begin{array}{l}\text { 22. Which of the following is not a way to encourage } \\
\text { speech and language development or reinforce } \\
\text { communicative effort? } \\
\text { a. Set up situations in which the child can } \\
\text { communicate with others. } \\
\text { b. Pretend to understand the child, but do } \\
\text { not interrupt to make corrections. } \\
\text { c. Do not call attention to the child's speech } \\
\text { errors in the classroom. } \\
\text { d. If you have difficulty understanding the } \\
\text { child, ask her to repeat. }\end{array}$ & $70 \%$ & $80 \%$ \\
\hline
\end{tabular}

\section{Untrained Questions}

The performance from both groups was better than expected on items not covered in the self-directed inservice program. Table VII provides the data related 
to the untrained questions. Everyone in the control group correctly identified the most common cause of otitis media as eustachian tube dysfunction, compared to $60 \%$ in the experimental group. For the question related to expected benefits of a cochlear-implant for a school-aged child, $70 \%$ of the experimental group and $60 \%$ of the control group answered accurately. Fifty percent of the experimental group and $70 \%$ of the control group correctly responded to the inappropriateness of an inthe-canal style hearing aid for a school-aged child. Only one subject from each group correctly answered the question regarding the leading cause of acquired sensorineural hearing loss in children. 
TABLE VII

SUMMARY OF GROUP PERFORMANCE ON UNTRAINED QUESTIONS

\begin{tabular}{|c|c|c|}
\hline Question & $\begin{array}{c}\text { Experimental } \\
\text { Group } \\
\text { Percent Correct } \\
\end{array}$ & $\begin{array}{c}\text { Control } \\
\text { Group } \\
\text { Percent Correct } \\
\end{array}$ \\
\hline $\begin{array}{l}\text { 4. The most common cause of otitis media (i.e., } \\
\text { middle-ear infections) is: } \\
\text { a. eustachian tube dysfunction } \\
\text { b. swimming } \\
\text { c. childhood illnesses such as measles or } \\
\text { chicken pox } \\
\text { d. inheritance from one of the parents }\end{array}$ & $60 \%$ & $100 \%$ \\
\hline $\begin{array}{l}\text { 10. A cochlear-implant can be expected to provide } \\
\text { which of the following benefits for a school-aged child? } \\
\text { a. improved speech understanding over the } \\
\text { phone } \\
\text { b. improved speech understanding in the } \\
\text { classroom } \\
\text { c. improved ability to utilize speech cues } \\
\text { such as voicing and fundamental frequency } \\
\text { d. improved ability to read and spell }\end{array}$ & $70 \%$ & $60 \%$ \\
\hline $\begin{array}{l}\text { 18. An in-the-canal style hearing aid is not appropriate } \\
\text { for a school-aged child because } \\
\text { a. their ear is still growing } \\
\text { b. this type provided limited high-frequency } \\
\text { response due to feedback problems } \\
\text { c. limits in using direct audio input devices } \\
\text { with this style } \\
\text { d. all of these may be valid reasons } \\
\text { e. some of these are valid reasons }\end{array}$ & $50 \%$ & $70 \%$ \\
\hline $\begin{array}{l}\text { 24. The leading cause of acquired sensorineural } \\
\text { hearing loss in children is } \\
\text { a. ear infections } \\
\text { b. meningitis } \\
\text { c. allergies } \\
\text { d. inheritance }\end{array}$ & $10 \%$ & $10 \%$ \\
\hline
\end{tabular}




\section{Questionnaire}

After the subjects in the experimental group completed the post test, they were given a brief questionnaire regarding their thoughts on the self-directed inservice program. Appendix $\mathrm{H}$ contains that actual responses to the questionnaire. The first question asked if the subject felt better informed about hearing loss and how to meet the classroom needs of students with hearing impairments. All of these subjects said they were better informed. Many of the subjects commented on the program's usefulness as a reference when specific information is needed.

The second question asked whether the subject liked the self-directed approach to staff development. The majority of the subjects responded positively to this type of approach. Many subjects liked being able to work at their own pace, and several commented on the cost-effectiveness and easy accessibility to the material. Some subjects commented that they would like to have the opportunity to discuss the material with others and ask questions.

The third question asked for suggestions on additional topics in which the subject would like information. The following is a list of some of the respondents' suggestions: behavior management, causes of hearing loss, speech problems, technological advances to facilitate hearing. Additional comments reflected appreciation for the training opportunity and some additional recommendations. 


\section{Discussion}

The results support the research hypothesis that the self-directed program, "Meeting the Classroom Needs of Students with Hearing Impairments," was effective in changing the basic knowledge of regular education teachers regarding the classroom needs of students with hearing impairment. However, a greater difference between the two groups was anticipated, with the experimental group performing considerably better than the control group on all test items. Several factors affecting the small difference between the two groups could be hypothesized. The content and organization of the inservice program is one factor that may have affected the outcome of this study.

In the first section of the inservice program, "Implications of a Hearing Impairment," the experimental group performed extremely well on all of the questions ( $80 \%$ or better). None of the subjects in the control could correctly identify the pinna. However, over $90 \%$ of the control group knew half of the items in this section. While it appears that this section of the inservice program is strong, it is possible that some of the information presented was either common knowledge or could be easily deduced due to the multiple choice nature of the test.

In the section on "Behavior Manifestations of a Child with a Hearing Impairment," the experimental group performed well on all items and the control group performed well on all items except the question regarding problems that a 
student with a hearing impairment would not encounter in school $(70 \%$

Experimental Group and 40\% Control Group). These results suggest that this

portion of the inservice program is adequate, but again, the possibility exists that some of the information may be common knowledge among teachers, or that the test did not properly measure the contents of the inservice program.

It was anticipated that the experimental group would perform considerably better on test items taken from the "Hearing Aids" section of the inservice program. A review of the literature indicated that teachers lack information regarding hearing aids. In fact, a survey of 113 teachers conducted by Lass, Tecca, and Woodford (1987) revealed teachers were deficient in the area of knowledge, experience, and attitudes regarding hearing aids and individuals who wear hearing aids. Therefore, it was surprising that the experimental group did not perform better on these questions, since the inservice program contained detailed information on this topic. One possibility for the experimental group's poor performance is that the presentation of this material in the inservice program was unclear or confusing. Overall, the experimental group performed better than the control group, but it is clear that this section of the inservice program needs to be strengthened.

Both groups performed similarly on the last section of the inservice program, "Helping the Student with a Hearing Impairment in the Classroom." There was a ten percentage point difference between the groups on the questions about getting the attention of a child with a hearing impairment and encouraging 
speech and language development. Also, only one person from each group correctly answered the question about the child with a hearing impairment displaying difficulties in class. Many teachers verbally expressed to the researcher that they were confused by the wording of this last test item (question \#5). The material in this section of the inservice program contained a large amount of information that was difficult to adequately test in a multiple choice format. Another possibility for the similar performance of the two groups is that some of the information was already known to both groups.

In addition to the material covered in the inservice program, four untrained questions were included on the test. The responses on these questions were quite variable, with the control group performing better on some and the experimental group performing better on others, but overall, the results were much higher than anticipated.

One factor which could have affected the outcome of this study that has already been alluded to is that perhaps some of the subjects already knew much of the information covered in the inservice program. While this researcher attempted to assess subjects' experience with and knowledge of hearing impairment through a survey (Appendix C) prior to administration of the inservice program or post test, this information was difficult to ascertain. It was difficult because a person who has a child with a hearing loss that requires amplification would most likely be 
more knowledgeable than a person whose parent or grandparent has a hearing impairment.

Another factor that may have affected the outcome of this study is the post test. It is possible that the test design was not the most appropriate instrument to use in determining the effectiveness of the inservice program. An objective test with a multiple choice format was constructed to ensure accurate scoring. While a subjective format like that used in the pilot study within the inservice program was considered during the early stages of the study, it was later rejected to avoid the difficulties involved in establishing high inter-judge reliability. However, it is possible that the material covered in the inservice program did not lend itself well to objective questions since much of the information involved lists and detailed explanations (e.g., signs that may indicate hearing loss and examples of how hearing loss affects school-aged children in the classroom). This being the case, a subjective test may have been more appropriate. A subjective test, or perhaps a combination of both subjective and objective questions may have provided a clearer picture of the subjects' understanding of the content.

By completing the statistical and item-by-item analyses, strengths and weaknesses of the content and organization of the inservice program were identified. Based on the results, the following sections of the inservice program appeared to be strong: (1) Implications of a Hearing Impairment, (2) Behavior Manifestations of a Child with a Hearing Impairment, and (3) Helping the Student 
with a Hearing Impairment in the Classroom. The section on hearing aids was judged to be the least effective in conveying the needed information. This is a concern because Berg (1986) points out that the daily management of hearing aids is a serious problem in the schools. He further indicates that most regular classroom teachers, who are expected to monitor the aids, are not knowledgeable about how to troubleshoot hearing aids.

It is possible that the material on hearing aids was presented in a way that was confusing to the readers. However, it should be noted that the weaknesses in the inservice program were not as apparent as the strengths. Perhaps this was because the post test did not adequately measure the subjects' knowledge of the material covered in the inservice program.

While this researcher attempted to objectify the information gathered through this study, useful information came from the subjective comments made by subjects in the experimental group in response to the "Self-Directed Inservice Feedback" questionnaire. One subject wrote the following: "I felt the ideas presented were easy to understand and well organized. As a reference, I find the information helpful. I liked being able to recheck information and read at my own pace." Most of the subjects indicated that they felt better informed about hearing loss and how to meet the classroom needs of students with hearing impairments. In response to whether the subjects liked the self-directed inservice approach to staff development, one subject commented that the information was easier to learn in 
this format. Another subject stated that this format "is appropriate and very useful in an environment of limited resources and scant training opportunities. It's not as good as hands on experience with an instructor and students with hearing impairment."

In addition to the strengths and weakness of the inservice program itself, along with the possibility of choosing another test format, other variables could have influenced the outcome of the study. While most of the subjects indicated that they liked being able to recheck information and read at their own pace, a more effective means of conveying the information in a self-directed manner might be to set aside a few hours on a given day for the teachers to complete the program. An instructor could also be available to answer questions or clarify information as the teachers read the material, and the teachers could perhaps break up into small groups to discuss the contents of the program.

Lastly, a pre-test or in-depth interest survey might be beneficial in determining the exact information that should be included in the inservice program. For this study, a review of the literature determined the area of focus rather than teacher input, and a pre-test was not given because the researcher did not want to bias the subjects to the information they would be tested on in the post test. Perhaps these issues should be addressed in a future study. 


\section{CHAPTER V}

\section{SUMMARY AND IMPLICATIONS}

\section{$\underline{\text { Summary }}$}

Students with mild to moderate hearing losses, and some with severe hearing losses, are mainstreamed in a regular classroom for all or part of the day (Martin, Berstein, Daly \& Cody, 1988). While these students may require special education services, the classroom teacher plays a vital role in the overall education and daily management of a child with a hearing impairment (Hass, 1987). Villa (1989) reported that many school employees have not received adequate training to educate these students. Therefore, it becomes the school's responsibility to educate teachers through a comprehensive inservice training program.

A common means of providing inservice training has been a lecture/discussion workshop. However, given the time constraints of classroom teachers and large class sizes, this may not be the best method to educate today's teachers about the classroom needs of students with hearing impairment. One format for training teachers suggested by Lass et al. (1986) was a self-directed inservice program. Friedman, Lehrer, and Stevens (1993) indicated that a selfdirected program can be utilized as a cost-effective means of meeting the 
professional needs of educators. However, the data bank of information is minimal regarding the effectiveness of a self-directed inservice program to train teachers about the needs of students with hearing impairments.

This study sought to answer the following research question: Will a comprehensive self-directed inservice program which provides information about hearing loss, behavior manifestations of children with hearing impairment, hearing aid maintenance, and mainstreaming effect a change in the basic knowledge of regular education teachers regarding the classroom needs of students with hearing impairment? A group of 20 teachers were randomly assigned to either the experimental group or control group. Ten subjects received the inservice program and the other ten read a brief article. A post test was administered to both groups, and the experimental group also provided written comments regarding the inservice program.

The results revealed an increase in the basic knowledge of regular education teachers about the classroom needs of students with hearing impairments. While the experimental group did not perform as well as expected, these results do suggest that a self-directed inservice program is a viable method of educating teachers about the needs of students with hearing impairments. 


\section{$\underline{\text { Implications }}$}

\section{Clinical Implications}

This study has shown that it is possible to increase the basic knowledge of regular education teachers about the classroom needs of students with hearing impairments through the use of a self-directed inservice program. This information could be beneficial to school districts in terms of the types of inservice they provide for their teachers. While these findings do not suggest that a self-directed approach to inservice training is more effective than a traditional lecture/discussion format, school districts that are not currently providing any trianing for their teachers in this area might find this approach beneficial. Another benefit is that a self-directed inservice program such as the one presented here might prove to be more cost effective.

Teachers may also find this type of inservice training more appealing since it can be completed at their own pace and used as a reference guide later. By educating teachers about the needs of students with hearing impairments, this may increase the overall success of mainstreaming students with hearing impairments.

\section{Research Implications}

Further development and expansion of the information in this self-directed inservice program is suggested. In particular, the section on hearing aids should be further developed and strengthened to insure a greater increase in teachers' 
knowledge about hearing aids. Additional ways to strengthen the program might be: (a) make the suggested changes, administer the inservice program, and then meet with the subjects who completed the program to discuss areas of strength and weakness in the program. (b) administer a pre-test to determine areas of need and then construct the inservice program around those needs.

Another suggestion might include developing a different instrument to measure the knowledge gain of the teachers. One possibility is to administer a post test composed of both objective and subjective test items. Further research is needed to determine the effectiveness of this program in an upgraded form prior to implementation. As indicated above, this program is lacking in necessary information that could be beneificial in educating teachers about the classroom needs of children with hearing impairment.

An alternative method of administration might be to have all the subjects meet at an appointed time after completing the self-directed inservice program with an instructor present to answer questions and lead a discussion among the teachers; however, this seems to go a step beyond a pure self-directed model.

This study was not designed to measure the level of impact of the training on changes in classroom instruction. Rather, it focused on differences between treatment and comparison groups. While the original question of this study has been answered, it would be also be advantageous to examine the effectiveness of a self-directed inservice program on hearing impairment versus a lecture/discussion 
inservice. The question of transfer of skills to the classroom should also be addressed. 


\section{REFERENCES}

Antia, S. (1985). Social integration of hearing-impaired children: Fact or fiction? The Volta Review, 87, 279-289.

Beaver, D., Hayes, P., \& Luetke-Stahlman, B. (1995). In-service trends: General education teachers working with educational interpreters. American Annals of the Deaf, 140, (1), 38-42.

Berg, F. S. (1987). Facilitating Classroom Listening. Boston, MA: Little, Brown, and Company, Inc.

Berg, F. S., Blair, J. C., Viehweg, S. H., \& Wilson-Vlotman, A. (1986). Educational Audiology for the Hard of Hearing Child. Orlando, FL: Grune \& Stratton, Inc.

Blair, J., Peterson, M., \& Viehweg, S. (1985). The effects of mild sensorineural hearing loss on academic performance of young school-age children. The Volta Review. 87. (2) 87-93.

Bynum, M. M., \& Rosenblatt, N. (1984). Self-study: Boon or bust? Training, 21, (11), 61-64.

Davis, J. (1994). Performance of young hearing-impaired children on a test of basic concepts. Journal of Speech and Hearing Research. 17, 342-351. 
Davis, J. (Ed.). (1977). Our Forgotten Children: Hard-of Hearing Pupils in the Schools. Minneapolis, MN: Audio Visual Library Service, University of Minnesota.

Davis, J. M., \& Shepard, N. T., Stelmachowicz, \& Gorga, M. P. (1981). Perceptions of hearing impairment held by school personnel: Suggestions for inservice training development. Language. Speech, and Hearing Services in Schoos, 7. $168-177$.

Davis, J., \& Blasdell, R. (1975). Perceptual strategies employed by normalhearing and hearing-impaired children in the comprehension of sentences containing relative clauses. Journal of Speech and Hearing Research, 18, (2) 281295.

Davis, J., Elfenbein, J., Schum, R., \& Bentler, R. (1986). Effects of mild and moderate hearing impairments on language, educational, and psychosocial behavior of children. Journal of Speech and Hearing Disorders, 51, 53-62.

Fisher, L. (1976). Fisher's Auditory Problems Checklist. Bemidji, MN: Life Products.

Fitch, J. L. (1982). Orientation to hearing loss for educational personnel. Language. Speech, and Hearing Services in Schools. 13, 252-259.

Flexer, C. (1994). Facilitating Hearing and Listening in Young Children. San Diego, CA: Singular Publishing Group, Inc. 
Friedman, G., Lehrer, B., and Stevens, J. (1983). The effectiveness of selfdirected and lecture/discussion stress management approaches and the locus of control of teachers. American Educational Research Journal, 20 (4), 563-580.

Hendrickson, J., O’Shea, D., Gable, R. A., Heitman, S., \& Sealnder, K. (1993). Putting a new face on an old strategy: Inservice preparation for the 21st century. Preventing School Failure. 37. (2) 31-35.

Holt, J. (1994). Classroom attributes and achievement test scores for deaf and hard of hearing students. American Annals of the Deaf. 139, (4), 430-436.

Kelly, E.J., \& Vanvactor, J.C. (1983). The Relative Cost Effectiveness of In-service Approaches in Remote, Sparsely Populated Schools. Exceptional Children, 50, (2), 140-148.

Lass, N. J., Tecca, J. E., \& Woodford, C. M. (1987). Teachers' knowledge of, exposure to, and attitudes toward hearing aids and hearing aid wearers. Language. Speech, and Hearing in Schools. 18, 86-95.

Lass, N., Carlin, M., Woodford, C., Campanelli-Humphreys, A., Judy, J., Hushion-Stemple, E., \& Boggs, J. (1986). A survey of professionals' knowledge of and exposure to hearing loss. The Volta Review. 88, 333-337.

Let's talk: Deaf culture. (1995, April). ASHA, 37, (4), P. 59.

Luckner, J. L. (1991). Mainstreaming hearing-impaired students: perceptions of regular educators. Language. Speech, and Hearing Services in Schools. 22, 302-307. 
Martin, F. N., Bernstein, M. E., Daly, J. A., \& Cody, J. P. (1988).

Classroom teacher's knowledge of hearing disorders and attitudes about mainstreaming hard-of-hearing children. Language. Speech, and Hearing Services in Schools, 19, 83-95.

Maxon, A., \& Brackett, D. (1987). The hearing-impaired child in regular schools. Seminars in Speech and Language. 8. (4) 393-413.

Oller, D., \& Kelly, C. (1974). Phonological substitution processes of a hard-of-hearing child. Journal of Speech and Hearing Disorders, 39, 65-74.

Osborne, A., \& Dimattia, P. (1994). The IDEA's least restrictive environment mandate: Legal implications. Exceptional Children, 61, (1), 6-14.

Oyer, H., Crowe, B., \& Haas, W. (1987). Speech. Language, and Hearing Disorders. Boston, MA: Little, Brown, \& Company.

Roeser, R. \& Downs, M. (1981). Auditory Disorders in School Children: The Law, Identification and Remediation. New York: Thieme-Stratton, Inc. Ross, M. (1978). Mainstreaming: Some social considerations. The Volta Review, 80, 21-30.

Schow, R. L. \& Nerbonne, M. A., (1989). Introduction to Aural Rehabilitation (2nd Ed). Austin, TX: Pro-Ed, Inc.

Simko, C. (1986). Wired for Sound: An Advanced Student Workbook on Hearing and Hearing Aids. Washington, D.C.: Gallaudet University Press. 
Sparks, D., \& Loucks-Horsley, S. (1989). Five Models of Staff

Development for Teachers. Journal of Staff Development, 10, (4), 40-57.

Villa, R. A. (1989). Model public school inservice programs: Do they exist? Teacher Education and Special Education. 12, (4), 173-176.

Wayner, D. (1990). The Hearing Aid Handbook: User's Guide for

Children. Washington, D.C.: Galludet University Press.

West, J., \& Weber, J. (1974). A phonological analysis of the spontaneous language of a four-year old hard-of-hearing child. Journal of Speech and Hearing Disorders, 38, 25-35.

Willeford, J. \& Burleigh, J. (1985). Handbook of Central Auditory Processing Disorders in Children. Orlando, FL: Grune \& Stratton, Inc. 
APPENDIX A

RECRIUTMENT LETTER 


\section{Dear Teachers,}

My name is Michelle Whiteley and I am a graduate student in Speech-Language Pathology at Portland State University. My thesis project involves using a selfdirected inservice program as a tool for educating teachers about the classroom needs of students with a hearing impairment.

If you choose to participate, I will come to your school and deliver the self-directed program, along with instructions on how to complete it. You will be given one week to complete the program. At that time, I will collect the programs. Four weeks later, I will come to your school and administer a written examination to measure the effectiveness of the program. The amount of time to complete the selfdirected program is approximately 2 hours. If you are willing to participate in this study please sign the attached release and I will contact you by phone to schedule a time to administer the program.

Thank you for your time.

Michelle Whiteley 
APPENDIX B

PORTLAND STATE UNIVERSITY

INFORMED CONSENT LETTER 


\section{PORTLAND STATE UNIVERSITY \\ INFORMED CONSENT}

1. I, agree to take part in this research project on a selfdirected inservice program entitled, "The Effectiveness of a Self-Directed Inservice Program to Educate Classroom Teachers About the Classroom Needs of Students with Hearing Impairment, conducted by Michelle Whiteley.

2. I understand that if I am assigned to the experimental group, this study will involve completing a survey ( 3 minutes), reading a booklet of information ( $11 / 2$ hours), and taking a post test on the material covered in the booklet (10 minutes). I further understand that if I am assigned to the control group, this study will inolve completing a survey ( 3 minutes), reading a brief article ( 15 minutes), and taking a post test ( 10 minutes).

3. I understand that there are not any risks to me associated with this study

4. I understand that the purpose of the study is to determine whether a self-directed inservice program is an effective method in educating regular education teachers about the classroom needs of students with a hearing impairment.

5. I understand that there will be no direct benefits to me by participating in this study, but my participation may help to increase knowledge which may benefit others in the future.

6. Michelle Whiteley has offered to answer any questions I have about the study and what I am expected to do. Her phone number is (360) 834-6270.

7. I understand that all information I give will be kept confidential and my name will not be used for publication or public discussions purposes.

8. I understand that participation is of a voluntary nature and the decision to withdraw from participation in this study at anytime will not affect my relationship with Portland State University or any other person agency.

I have read and understand the above information and agree to participate in this study.

Date: Signature:

If you have any concerns or questions about this study, please contact the Chair of Human Subjects Research and Review Committee, Research and Sponsored Projects, 105 Neuberger Hall, Portland State University, 503/725-3417. 
APPENDIX C

SURVEY OF TEACHER'S EXPERIENCE AND KNOWLEDGE OF

HEARING IMPAIRMENT 


\section{Survey of Teacher's Experience and Knowledge of Hearing Impairment}

Name:

Phone:

\section{Background Information}

1. Current grade taught:
a. Kindergarten
b. 1 st
c. 2nd
d. 3 rd
e. 4 th
f. 5 th
g. 6 th

2. Circle all grades taught, including present:
a. Kindergarten
b. 1 st
c. 2nd
d. $3 \mathrm{rd}$
e. 4 th
f. 5 th
g. 6 th

3. Indicate the number of years you have taught school:

\section{Experience with Hearing Impairment}

1. Do you have a hearing impairment?
a. Yes
b. No

If yes, do you wear a hearing aid?
a. Yes
b. No 
2. Do you have any family members who have a hearing impairment?

If yes, who (e.g., mother, son, uncle, etc.):

3. Do you know any children who have a hearing impairment?
a. Yes
b. No

4. Have you taught any students with hearing impairments during you teaching career?
a. Yes
How many?
How long ago?
b. No

5. Have you had specific training related to hearing impairment?
a. Yes
b. No

If yes, did the training occur: (circle all that apply)

a. as part of your undergraduate or graduate education

b. through inservices, courses, workshops, conferences, seminars, etc.

Please provide a brief explanation of the specific training, including approximate dates: 
APPENDIX D

SELF-DIRECTED INSERVICE PROGRAM 


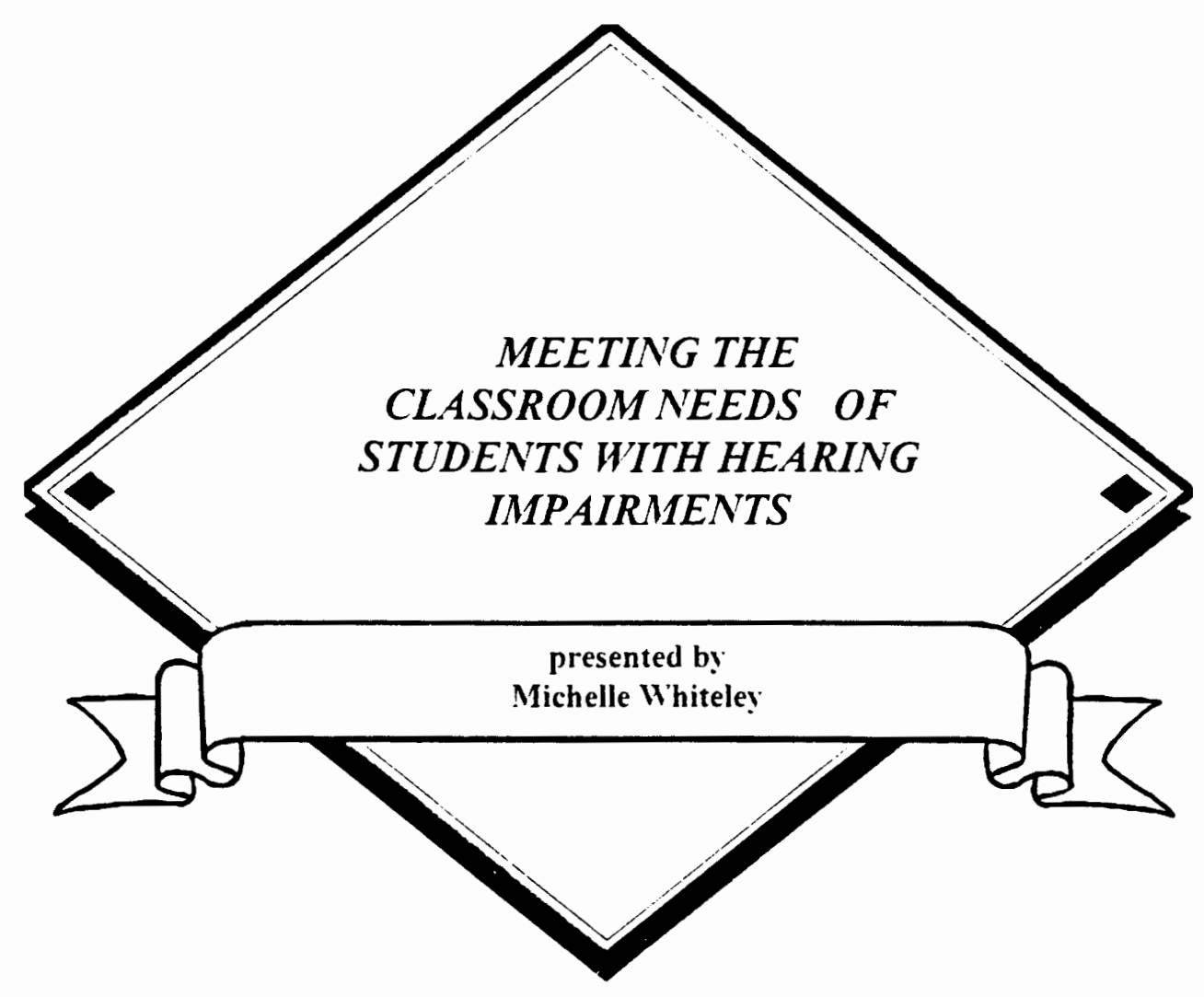




\section{TEACHER INSERVICE: HEARING IMPAIRMENT}

I. Implications of a hearing impairment
A. Hearing and your ears
B. What a hearing loss means
C. Students with a hearing impairment: Educational considerations and special needs

II. Behavior manifestations of a child with hearing impairment or central auditory processing disorder
A. Behavior manifestations
B. Fisher's auditory problems checklist
C. Willeford and Burleigh's behavior rating scale for central auditory disorders

III. Hearing aids
A. What is an audiogram?
B. Different kinds of hearing aids
C. A hearing aid checklist
D. Tips for troubleshooting a student's hearing aid

IV. Helping the student with a hearing impairment in the classroom
A. Concerns of the regular education teacher
B. ldeas for helping students with hearing impairments in the classroom
C. Gestures and facial expressions that can be used in the classroom 


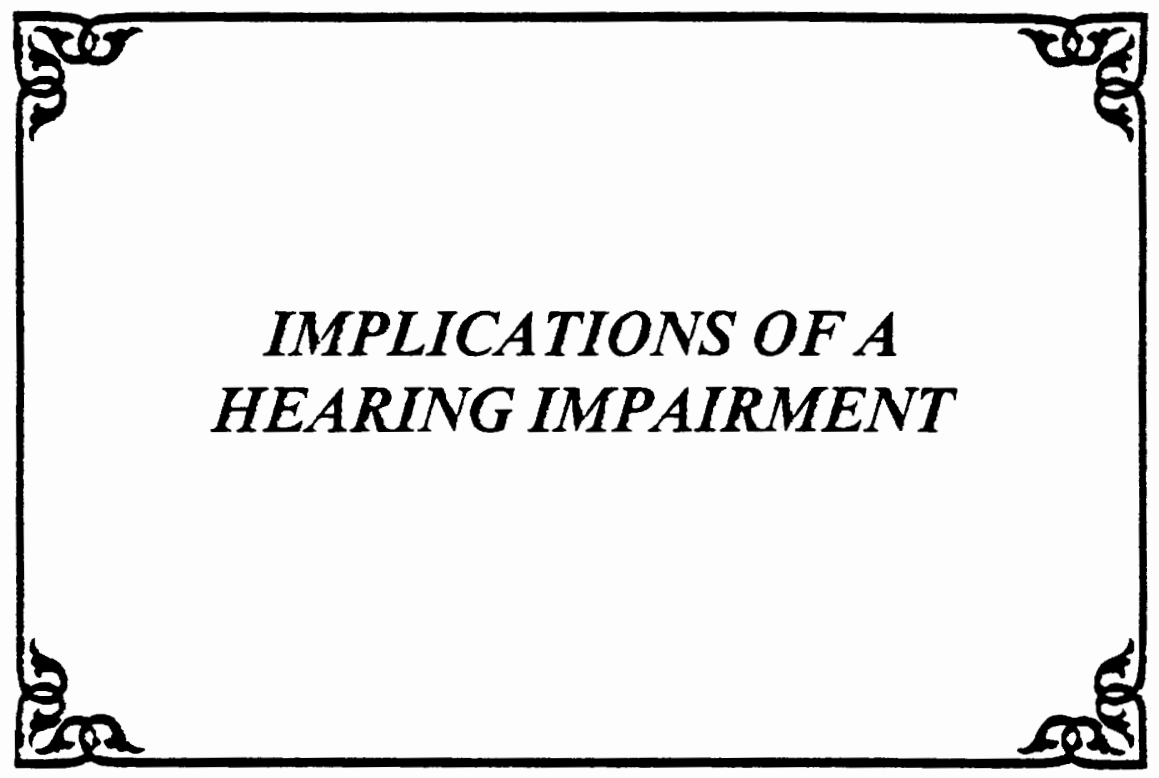




\section{HEARING AND YOUR EARS}

Everyone know's that our ears are for hearing. Our world is filled with thousands of sounds to hear. These sounds help us to learn about our world. We listen to sounds all day long, but we never think about what makes us hear them. When someone talks or a dog barks, do you ever wonder how you hear it?

Here is what the whole ear would look like if you could see it:

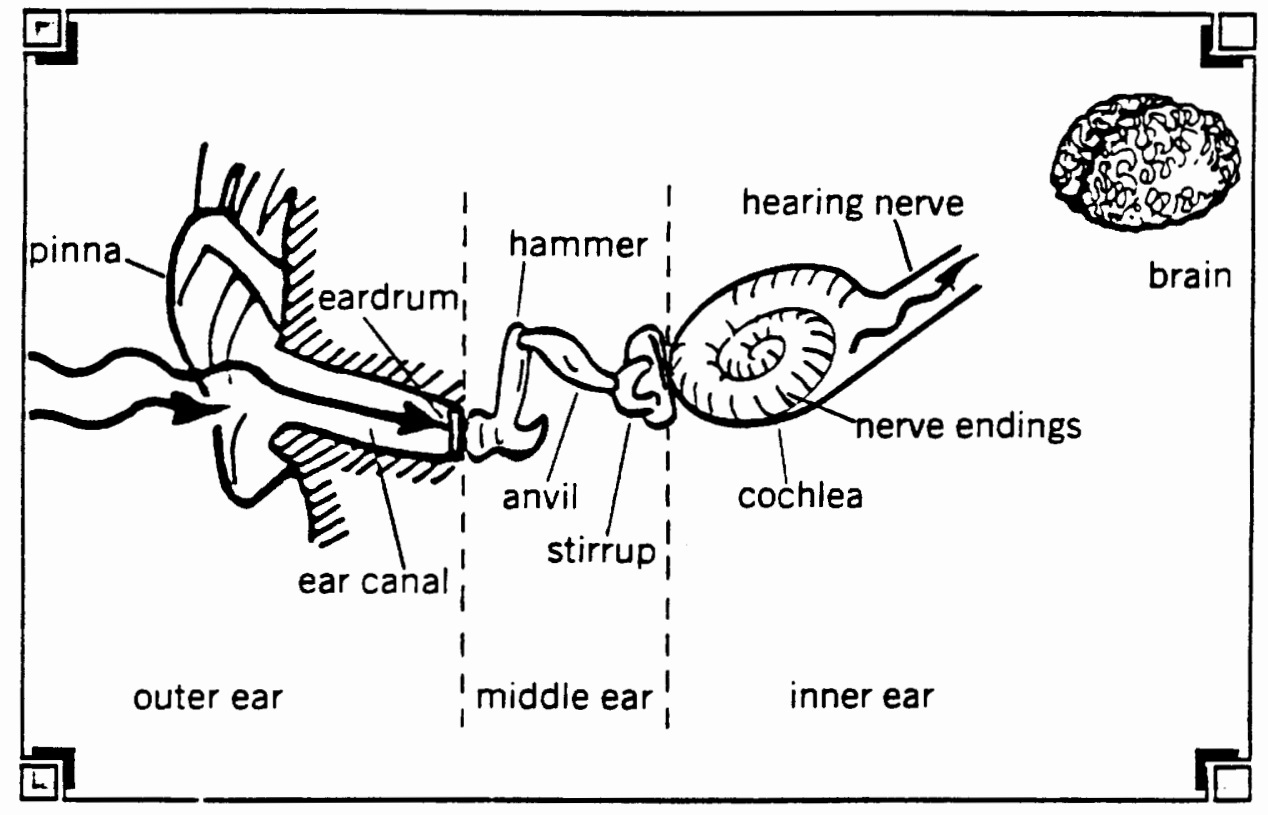

\section{The Parts of the Ear}

The ear is divided into three main sections: the outer ear, the middle ear, and the inner ear. Sound passes through all three sections of the ear before it goes to the brain. The brain interprets the sounds and tells us what we are hearing. 
Outer Ear--Sound enters through the outer ear.

- pinna--The part of the outer ear we see. It catches the sound.

- ear canal--Sound travels from the pinna through the ear canal.

- eardrum--The sound pushes against our eardrum. The eardrum lies between the outer ear and the middle ear. It is a little opening covered with skin. kind of like a drum. Sound hits the eardrum and makes it vibrate.

Middle Ear--Contains the three smallest bones in the body.

- Hammer These bones are so small they could fit on a dime.

- Anvil When the eardrum moves. it makes the three bones

- Stirrup move.

\section{Inner Ear}

- cochlea--Shaped like a snail, it has thousands of tiny' nerve endings inside it.

- 8th cranial nerve--The nerve endings in the cochlea lead to the 8 th cranial nerve. The nerve endings in the cochlea are tuned somewhat like the key's on a piano. Some of the nerve endings respond to low sounds. and some respond to high sounds. The 8 th cranial nerve connects the cochlea with the brain.

The three sections of the ear work together to help us hear. This is what happens: sounds hit the eardrum. so the eardrum starts to vibrate. The vibrations make the hammer. anvil, and stirrup move. This causes the nerve endings in the cochlea to move. The nerve endings send a message to the 8 th cranial nerve. The 8 th cranial nerve carries the message to the brain. The brain tells us what we are hearing.

Simko. 1986 


\section{WHAT A HEARING LOSS MEANS}

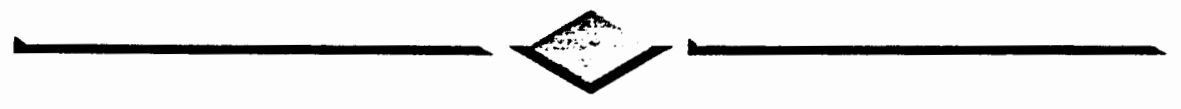

In order to understand how hearing loss affects school-aged children, you must first have some knowledge of the nature of hearing.

- Hearing loss is difficult to understand for two reasons: (a) it doesn't look disabling. and (b) it is so different in each child that guidelines are almost impossible to establish.

Example: Mary and Tom have a 35\% hearing loss in both ears. While you might expect both children to hear about the same on all occasions. this is not the case. Mary. with a conductive hearing loss. understands you easily when you speak a little louder or move a little closer. Tom. who has a sensorineural hearing loss with a significant high frequency loss. is confused only by louder speech. Mary hears fine in a noisy gy'm class. but Tom has more trouble hearing in that class than any other.

- Hearing loss often results in a breakdown of communication between any two people. Both sides may experience feelings of insecurity and helplessness when there is no clear-cut answer, good for all occasions. to the question, "Did he or she understand what I said?"

Example: When you ask Mary to wash the blackboard, she sits there with a puzzled expression on her face until you repeat the request again while both of you are building up frustration. It turns out that Mary thinks you want her to watch the blackboard. She thinks you are going to write something. Wash and watch look alike as you see them spoken. Since Mary's poor hearing can 't discriminate between the two words. a breakdown in the communication process occurs. and misunderstanding. insecurity, and irritation widen the gap. 


\section{STUDENTS WITH HEARING IMPAIRMENTS: EDUCATIONAL CONSIDERATIONS \& SPECIAL NEEDS}

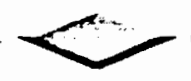

A student with a hearing impairment is a student who has a hearing loss. Some students who cannot hear well may have trouble learning in school. The following list of problems may be present in students with a hearing impairment:

- Difficulty in hearing what teachers or other students say

- Trouble hearing films in school

- Difficulty in understanding directions

- Difficulty in formulating sentences

- Speech problems. specifically the following sounds: $s, z, s h$, ch, $f$ \& th

- Reading. spelling. or English grammar difficulty

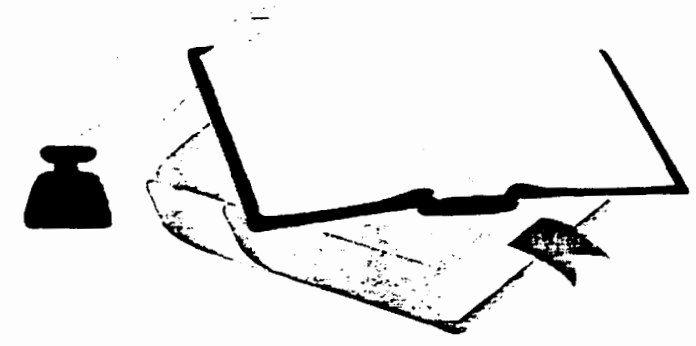

A hearing aid helps most students with a hearing loss:

- A hearing aid makes sounds and speech much louder.

- An aid helps students to hear their teachers and classmates better. although it does not enable a person to hear in the same way that glasses enable a person to see with 20/20 corrected vision.

- Students with a hearing impairment must learn how to wear a hearing aid and how to take care of it.

- They must learn to listen to sounds through the hearing aid.

- They must learn to tell the difference between a dog barking, a bell ringing. or a person talking.

- They must learn to tell the difference between words that sound alike. such as mat and bat. 
Speechreading helps students with a hearing loss know what someone is saying.

- These students often read lips to understand speech..

- They learn to watch a speaker's face. body movements. and mouth movements.

- These students learn the lip and tongue movements that go with each sound.

- They learn that facial expressions and movements can help them understand what a speaker is talking about.

Sinko. 1986 


\section{EXERCISE}

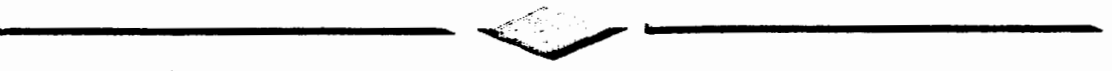

1. Describe hou the three sections of the ear work together to help us hear.

2. Give one example of how hearing loss often results in a breakdown of communication between two people.

3. List several problems that a student with a hearing impairment may encounter in school. 


\section{ANSWERS}

1. Describe how the three sections of the ear work together to help us hear.

As sounds hit the eardrum, the eardrum starts to vibrate. The vibrations make the hammer, anvil, and stirrup move. This causes the nerve ending in the cochlea to move. The nerve endings send a message to the hearing nerve. The hearing nerve carries the message to the brain. The brain tells us what we are hearing.

2. Give one example of how a hearing loss often results in a breakdown of communication between two people.

When you ask Mary to wash the blackboard, she sits there with a puzzled expression on her face until you repeat the request again while both of you are building up frustration. It turns out that Mary thinks you want her to watch the blackboard. She thinks you are going to write something. W'ash and watch look alike as you see them spoken. Since Mary's poor hearing can't discriminate between the two words, a breakdown in the communication process occurs, and misunderstanding, insecurity, and irritation widen the gap.

3. List several problems that a student with a hearing impairment may encounter in school.

- Difficulty in hearing what the teacher or other students say

- Trouble hearing films in school

- Difficulty in understanding directions

- Difficulty in formulating sentences

- Speech problems, specifically the following sounds: $s, z, s h, c h, f, \& t h$

- Reading, spelling. or English difficulty 


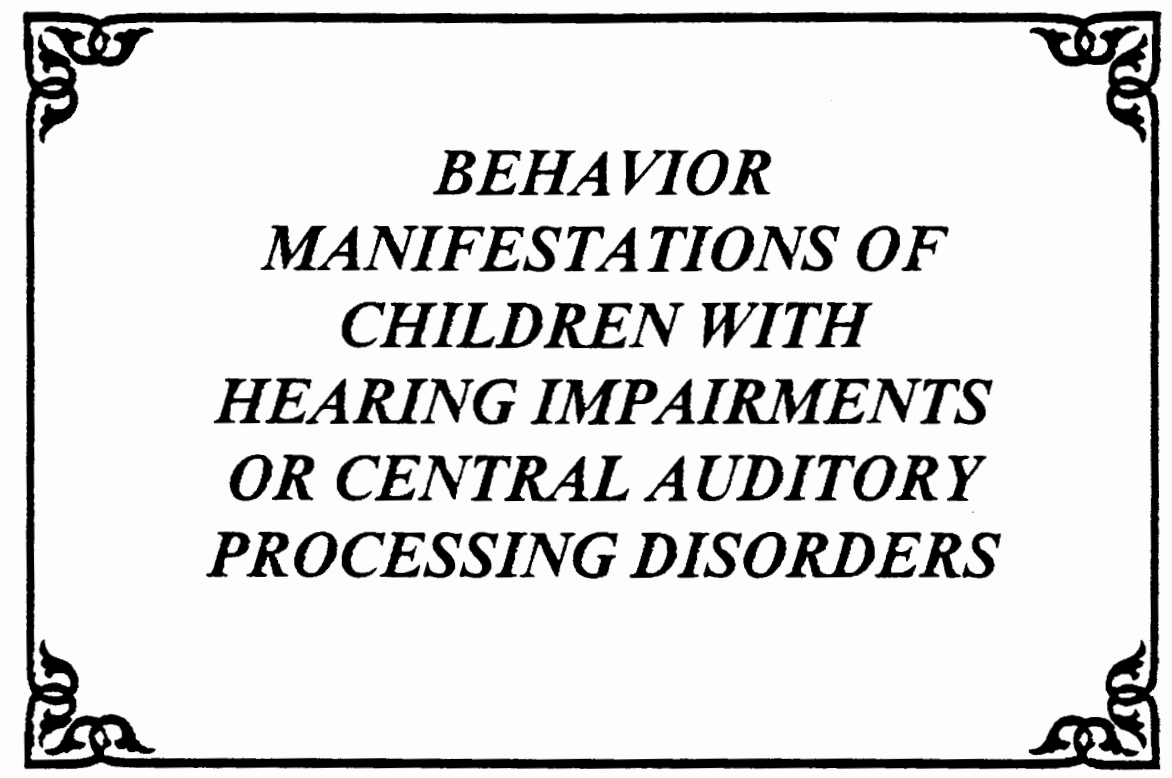




\section{BEHAVIOR MANIFESTATIONS}

\section{SIGNS THAT MAY INDICATE HEARING LOSS}

\section{BEHAVIORS}

- Noncompliant behavior

- Responds inconsistently/inappropriately to sounds or spolien communication

- Prefers loud volumes (This child may frequently be found sitting too close to audio equipment or a person speaking.)

- Withdraws from activities and tends to isolate self

- Appears to be uncomfortable or confused in noisy situations

- Talks too loud or too soft

- Frequently asks to have things repeated

- Turns one side of head toward speaker

- Shows strain in trying to hear

- Watches and concentrates on teacher's lips

- Is inattentive in classroom discussions

- Makes frequent mistakes in following directions

- May be tense

- Has a speech problem

- Is not working up to apparent ability.

PHYSICAL SYMPTOMS

- Mouth breathing

- Draining ears

- Earaches

- Dizziness

- Reports of ringing. buzzing or roaring in ears 
- The sound of a word travels past your ear at a rate of 1120 feet per second and is gone forever. There is no opportunity for "a second take" as there is in reading print.

Example: Tom is distributing papers to some classmates. Each paper has the name of one child. If he doesn't get a name at first glance. he can look again--with no bother to anyone. However. the situation is quite different if the teacher say's. "Give papers to ." If Tom doesn"t hear--or forgets--he must ask anain. because the sound of the name has faded into the land of no return where no second impression is possible. He must "bother" someone because of the physical nature of sound.

- Hearing is affected considerably by the physical and emotional health of the child.

Example: Mary may understand the principal when she is sent on a happy errand. but may have a truly miserable time hearing if she is sent to the office for misbeharing in the classroom.

Way'ner. 1990 


\section{BEHAVIORS COMMONLY FOUND IN CHILDREN WITH CENTRAL AUDITORY PROCESSING DISORDERS}

The primary purpose of this inservice program is to address problems faced by children with hearing impairment in the mainstream classroom. However. many of the behavior manifesations presented may also be seen in children with central auditory processing disorders.

Common characteristics of children with central auditory processing disorders are listed below: If you have concerns about children in your classroom who are exhibiting these behaviors, the following pages contain two checklists which can be completed and given to a speech-language pathologist or audilogist for possible referral. The information provided on the checklist will be helpful in determining whether an audiological evaluation should be administered.

- Poor listener due to lack of awareness of sounds

- Poor attention span

- Easily distracted

- Often misunderstands

- Trouble following verbal instructions

- Frustrated

- Poor speech discrimination

- Poor ability to organize information

- Seems to have poor memory

- Slow starter

- Doesn't complete tasks

- Daydreams

- Hyperactive or hypoactive

- Display's hostility

- Is disruptive

- Withdrawn - often plays by self

- Prefers company of "younger" friends or adults

- "Sof.." if any.. neurological signs

- A young child "clings" to parents in active environments

- Seeks quiet or structured environment 


\section{FISHER'S AUDITORY PROBLEMS CHECKLIST}

Student's Name:

Grade:
Date:

()bserver:

Please place a check mark before each item that is considered to be a concern by the observer.

1. History of hearing loss.

2. History of ear infections(s).

3. Does not pay attention to instructions most of the time.

4. Does not listen carefully to directions - it is often necessary to repeat instructions.

5. Says "Huh?" or "What?" at least five times per day.

6. Cannot attend to auditory stimuli for more than a few seconds.

7. Has a short attention span. $0-2$ minutes 5-15 minutes $2-5$ minutes 15-30 minutes

8. Daydreams--attention drifts--not "with it" at times.

9. Easily distracted by background noise.

10. Has difficulty learning phonics.

11. Displays problems with sound discrimination.

12. Has trouble recalling a sequence that was heard.

13. Forgets what is said in a few minutes.

14. Does not remember simple routine activities from day to day.

15. Does not recall what was heard last week. month. year.

16. Difficulty following auditory directions.

17. Often misunderstands what is said.

18. Does not comprehend many words - verbal concepts for age grade level.

19. Slow or delayed response to verbal stimuli is apparent.

20. Has a language problem(s).

21. Has an articulation or phonological problem.

22. Cannot alway's relate what is heard with what is seen.

23. Learns poorly through the auditory channel.

24. Lacks motivation to learn.

25. Performance is below average is one or more subject area(s).

Scoring: Four percent credit for each numbered item not checked.

Number of items not checked $\mathrm{x} 4=$

Fisher, 1976 


\section{WILLEFORD AND BURLEIGH'S BEHAVIOR RATING SCALE FOR CENTRAL AUDITORY PROCESSING DISORDERS}

Pre-Interventions Post-Intervention

Name Grade School

Observer Position Date

On a scale of 1 (never) to 5 (always), rate the student's ability on the following:

\begin{tabular}{|l|c|c|c|c|c|}
\hline & Never & Occasionally & Often & Usually & Alway's \\
\hline $\begin{array}{l}\text { 1. Has difficulty in paying attention } \\
\text { to speaker }\end{array}$ & 1 & 2 & 3 & 4 & 5 \\
\hline 2. Is a poor listener & 1 & 2 & 3 & 4 & 5 \\
\hline 3. Is disturbed by background noise & 1 & 2 & 3 & 4 & 5 \\
\hline SPECIFICALLY: & & & & & \\
\hline a. speech & 1 & 2 & 3 & 4 & 5 \\
\hline b. whispering & 1 & 2 & 3 & 4 & 5 \\
\hline c. shuffling papers, feet. etc... & 1 & 2 & 3 & 4 & 5 \\
\hline d. pencil sharpener & 1 & 2 & 3 & 4 & 5 \\
\hline e. playground noise & 1 & 2 & 3 & 4 & 5 \\
\hline f. other classrooms or halls & 1 & 2 & 3 & 4 & 5 \\
\hline g. other & 1 & 2 & 3 & 4 & 5 \\
\hline 4. Daydreams & 1 & 2 & 3 & 4 & 5 \\
\hline 5. Has short attention span & 1 & 2 & 3 & 4 & 5 \\
\hline $\begin{array}{l}\text { 6. Misunderstands verbal } \\
\text { instructions }\end{array}$ & 1 & 2 & 3 & 4 & 5 \\
\hline $\begin{array}{l}\text { 7. Misunderstands written } \\
\text { instructions }\end{array}$ & 1 & 2 & 3 & 4 & 5 \\
\hline 8. Asks to repeat verbal instructions & 1 & 2 & 3 & 4 & 5 \\
\hline $\begin{array}{l}\text { 9. Slow or delayed response to } \\
\text { verbal stiniuli }\end{array}$ & 1 & 2 & 3 & 4 & 5 \\
\hline $\begin{array}{l}\text { 10. Has trouble recalling verbal } \\
\text { material originally understood }\end{array}$ & 1 & 2 & 3 & 4 & 5 \\
\hline
\end{tabular}




\begin{tabular}{|c|c|c|c|c|c|}
\hline & Never & Occasionally & Ofien & Lsuall! & Always \\
\hline $\begin{array}{l}\text { ACADEMIC PROFILE } \\
\text { 1. Decreased performance in the } \\
\text { following subjects: }\end{array}$ & & & & & \\
\hline Mathematics & 1 & 2 & 3 & 4 & 5 \\
\hline Reading & ] & 2 & 3 & + & 5 \\
\hline Spelling & $!$ & 2 & 3 & 4 & 5 \\
\hline Phonics & 1 & 2 & 3 & 4 & 5 \\
\hline Language Arts & 1 & 2 & 3 & 4 & 5 \\
\hline Other & 1 & 2 & 3 & 4 & 5 \\
\hline 2. Slow starter & 1 & 2 & 3 & 4 & 5 \\
\hline 3. Difficulty completing tasks & ] & 2 & 3 & 4 & 5 \\
\hline $\begin{array}{l}\text { 4. Child relies heavily on visual } \\
\text { clues in classroom }\end{array}$ & ] & 2 & 3 & 4 & 5 \\
\hline 5 Receives resource-tutorial heip & 1 & $=$ & 5 & + & 5 \\
\hline $\begin{array}{l}\text { 6. Receives speech-language } \\
\text { therapy }\end{array}$ & ] & 2 & 3 & 4 & 5 \\
\hline $\begin{array}{l}\text { SOCIAL PROFILE } \\
\text { 1. Impulsive }\end{array}$ & 1 & 2 & 3 & 4 & 5 \\
\hline 2. Frustrated & 1 & 2 & 3 & 4 & 5 \\
\hline 3. Withdrawn & 1 & 2 & 3 & 4 & 5 \\
\hline 4. Aggressive & 1 & 2 & 3 & 4 & 5 \\
\hline 5 Not accepted by peers & 1 & 2 & 3 & 4 & 5 \\
\hline $\begin{array}{l}\text { 6. Prefers association with younger } \\
\text { children }\end{array}$ & l & 2 & 3 & 4 & 5 \\
\hline 7. Child is a "loner" & 1 & 2 & 3 & 4 & 5 \\
\hline $\begin{array}{l}\text { 8. Restlessiexcessive phy'sical } \\
\text { movement }\end{array}$ & 1 & 2 & 3 & $\overline{4}$ & 5 \\
\hline $\begin{array}{l}\text { 9. Disturbs other children during } \\
\text { class }\end{array}$ & 1 & 2 & $\overline{3}$ & 4 & 5 \\
\hline 10. Gives up easily & 1 & 2 & 3 & + & 5 \\
\hline 11. Seeks assistance from teacher & 1 & 2 & 3 & 4 & 5 \\
\hline $\begin{array}{l}\text { 12. Insensitive to time } \\
\text { responsibilities }\end{array}$ & 1 & 2 & 3 & 4 & 5 \\
\hline
\end{tabular}




\section{EXERCISE}

1. List behaviors that may indicate a hearing loss.

2. When should a teacher use Fisher's Auditory Problems Checklist? 


\section{ANSWERS}

1. List ten behaviors that may indicate a hearing loss.

- Noncompliant behavior

- Responds inconsistently/inappropriately to sounds or spoken communication

- Prefers loud volumes (This child may frequently be found sitting too close to audio equipment or a person speaking.)

- Withdraws from activities and tends to isolate self

- Appears to be uncomfortable or confused in noisy situations

- Talks too loudly or too softly

- Frequently asks to have things repeated

- Turns one side of head toward speaker

- Show's strain in trying to hear

- Watches and concentrates on teacher's lips

- Is inattentive in classroom discussions

- Makes frequent mistakes in following directions

- May be tense

- Has a speech problem

- Is not working up to apparent capacity

2. When should a teacher use Fisher's Auditory Problems Checklist?

A teacher should complete Fisher's Auditory Problems Checklist when behaviors are observed in the classroom that may indicate a hearing loss. After completing the checklist, it should be given to a speech-language pathologist or audiologist to determine whether a hearing test should be administered. The information provided on the checklist will be helpful in determining the direction of the evaluation. 


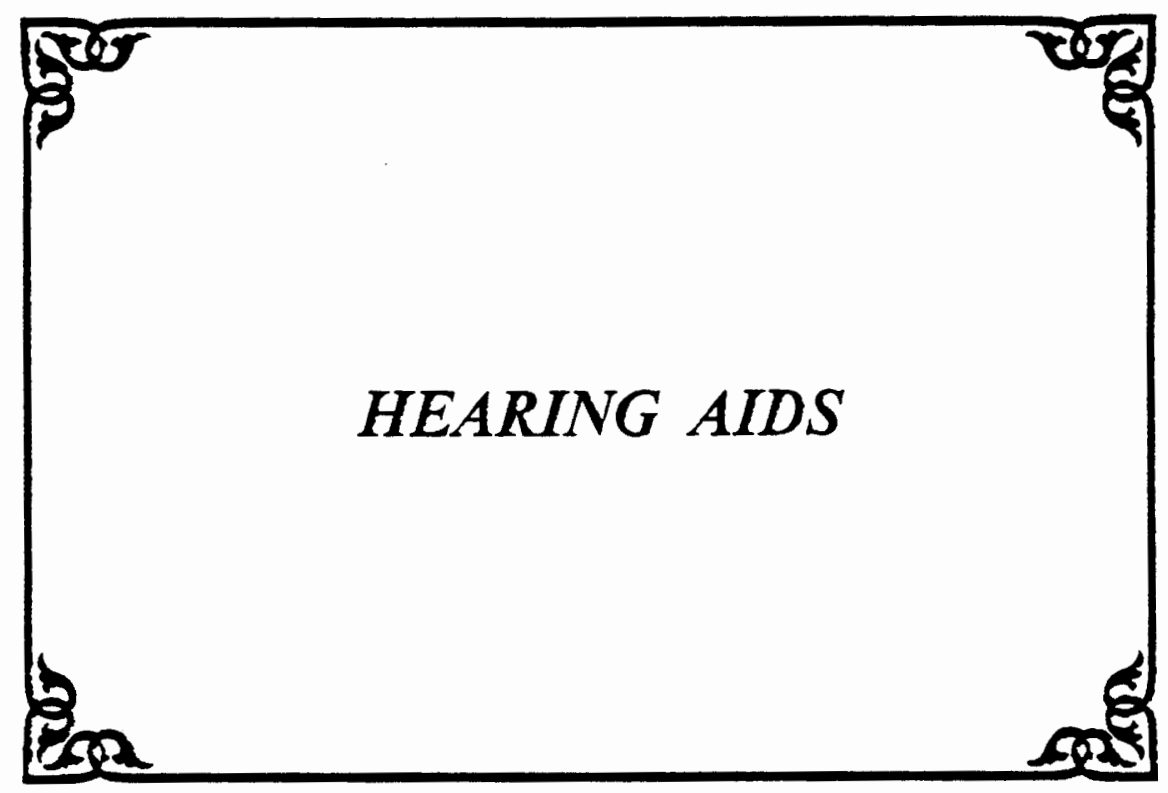




\section{WHAT IS AN AUDIOGRAM?}

- An audiogram is a simple graph that charts what a person can hear.

- The audiogram indicates how loud a sound needs to be for a person to just barely hear it.

- An audiogram show's the ty'pe of hearing loss (conductive. sensorineural. or mixed). the degree of hearing loss (ranging from minimal to profound). and the pattern of the hearing loss (how much hearing loss exists at different frequencies).

- Frequencies from $250 \mathrm{~Hz}$ to $8000 \mathrm{~Hz}$ are shown along the horizontal line and intensity or loudness in $\mathrm{dB}$ Hearing Level is displayed across the vertical line.

- The higher the number of decibels, the louder the sound.

This audiogram shows not only frequency (pitch) and intensity (loudness), but also the relationship of both to specific speech sounds and environmental sounds. On this audiogram. aided thresholds (A) show the softest tones that the child can hear while wearing his or her hearing aids, compared to unaided sound-field thresholds (S). which show the softest sounds that the child can hear without amplification. e.g.. hearing aid.

Flexer, 1994

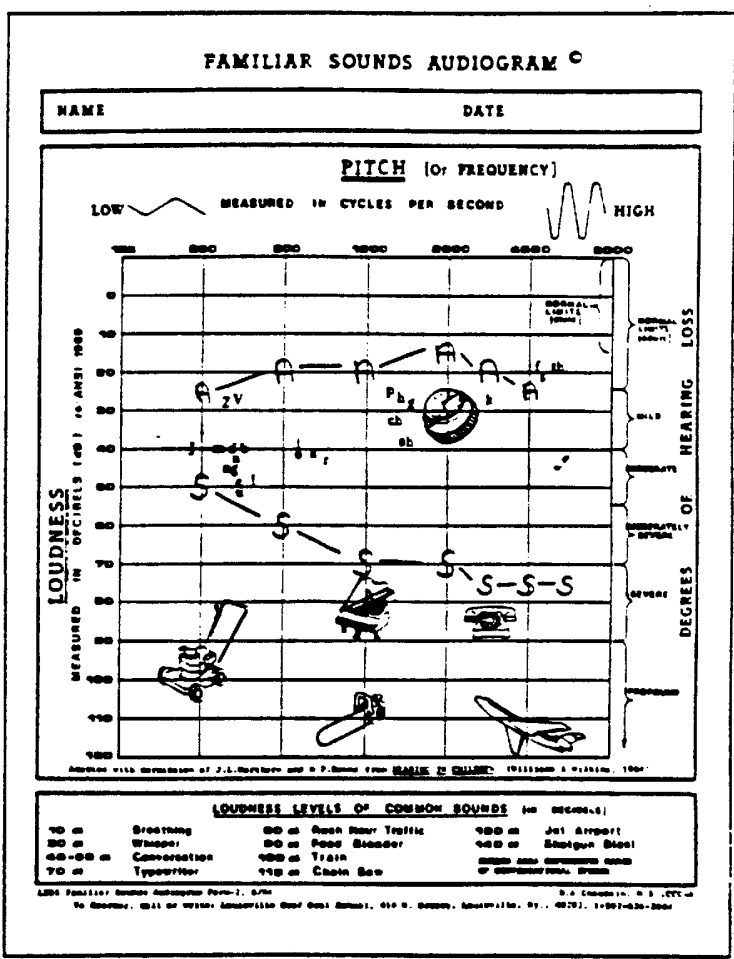




\section{DIFFERENT KINDS OF HEARING AIDS}

\section{Behind-the-Ear Hearing Aid} It is worn behind the ear and is held on the ear by a short hook. The hook carries sound from the aid to a tube.
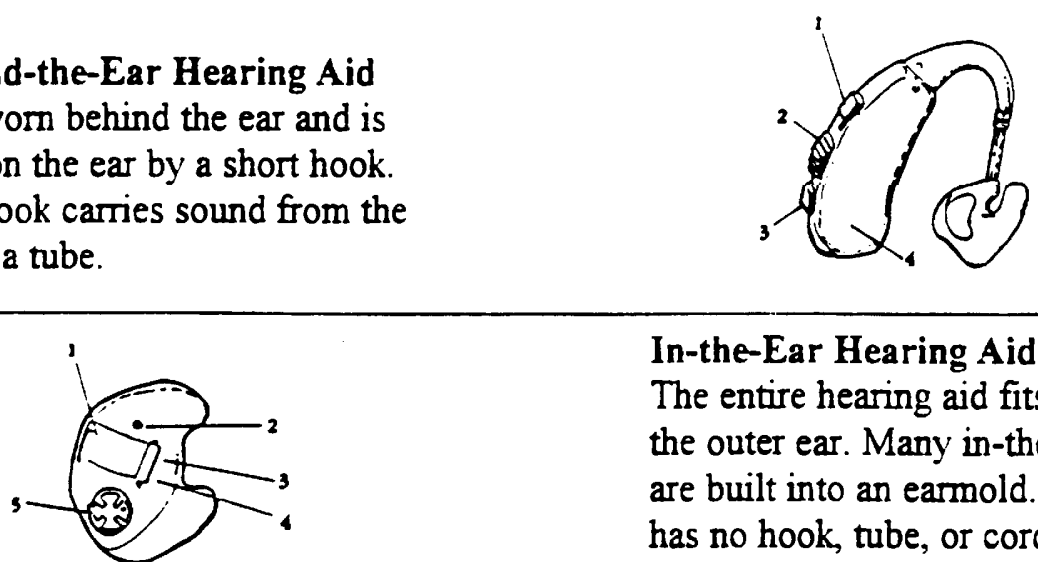

In-the-Ear Hearing Aid

The entire hearing aid fits inside the outer ear. Many in-the-ear aids are built into an earmold. This aid has no hook, tube, or cord.

\section{Canal Hearing Aid}

This aid fits primarily in the in the external auditory canal with only slight protrusion into the concha
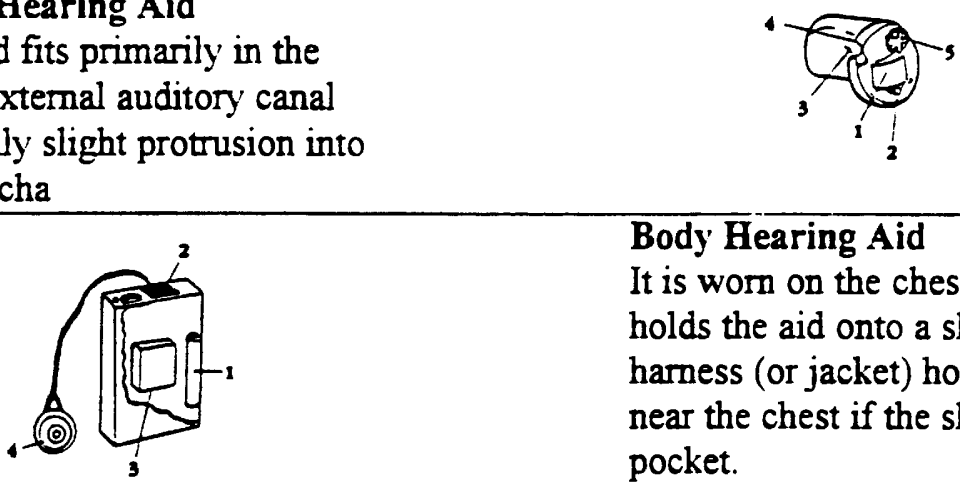
Body Hearing Aid
It is worn on the chest. A clip holds the aid onto a shirt. A harness (or jacket) holds the aid near the chest if the shirt has no pocket.

\section{Key}

1. Batten: The battery is the power source of the aid.

2. Microphone: The microphone converts sound waves into electrical energy.

3. Amplifier: The amplifier increases the strength of the electrical signal, boosting energy.

4. Receiver: The receiver converts the amplified electrical signal back into sound energy.

5. Volume Control: The volume control allow's the wearer to adjust the amplification to the most comfortable level.

Simko, 1986 and Wayner, 1990 


\section{HEARING AID CHECKLIST}

The following equipment is needed to check and troubleshoot hearing aids:

- Battery tester--To determine the strength of the battery.

- Airblower--To clear moisture out of the earmold.

- Wax remover--To clean ear wax out of the earmold.

- Tiny screwdriver--To make sound pressure level (SPL) and tone control adjustments.

- Hearing aid stethoscope--To conduct the daily listening check.

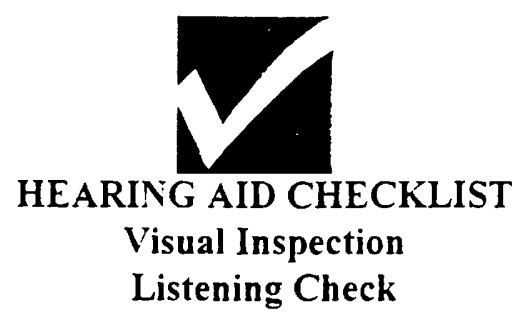

\begin{tabular}{|l|l|l|l|l|l|l|l|l|l|}
\hline Date & & & & & & & & & \\
\hline $\begin{array}{l}\text { Battery check: } \\
\text { (record voltage) }\end{array}$ & & & & & & & & & \\
\hline $\begin{array}{l}\text { Earmold/Tubing Appearance: } \\
\text { a) cerumen? } \\
\text { b) crackling? } \\
\text { c) moisture? }\end{array}$ & & & & & & & & & \\
\hline $\begin{array}{l}\text { Hearing aid appearance: } \\
\text { a) crackling? } \\
\text { b) volume control--smooth. } \\
\text { gradual increase } \\
\text { c) miscellaneous }\end{array}$ & & & & & & & & & \\
\hline $\begin{array}{l}\text { Ling 6 Sound Test } \\
\text { /u/./a/,/i/./s/./ /./m/ }\end{array}$ & & & & & & & & & \\
\hline Miscellaneous & & & & & & & & & \\
\hline
\end{tabular}

key: $\boldsymbol{\nabla}$ is adequate; - is inadequate

Flexer, 1994 


\section{TIPS FOR TROUBLESHOOTING A STUDENT'S HEARING AID}

\begin{tabular}{|c|c|c|}
\hline 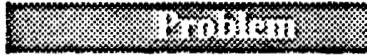 & 14 & (3) \\
\hline $\begin{array}{l}\text { "Dead" hearing aid } \\
\text { (no sound at all) }\end{array}$ & $\begin{array}{l}\text { 1. Battery dead. } \\
\text { 2. Batter + and - reversed } \\
\text { 3. Plugs (in cord type) } \\
\text { broken or dirty } \\
\text { 4. Cord broken } \\
\text { 5. Earmold or tubing } \\
\text { plugged } \\
\text { 6. Disconnected. twisted. or } \\
\text { kinked tubing } \\
\text { 7. Moisture in tubing } \\
\text { 8. Controls: } \\
\text { a. on-off switch } \\
\text { b. selector } \\
\text { c. volume }\end{array}$ & $\begin{array}{l}\text { 1. Replace battery } \\
\text { correctly placed } \\
\text { 3. Clean or replace cord } \\
\text { 4. Replace cord } \\
\text { 5. Clean } \\
\text { 6. Push tubing firmly onto } \\
\text { aid. straighten tubing } \\
\text { 7. Remove moisture (use } \\
\text { forced air earmold cleaner) } \\
\text { 8. Check controls: } \\
\text { a. Make sure it is "on" } \\
\text { b. Switch to "M" } \\
\text { (microphone) } \\
\text { c. Turn to appropriate } \\
\text { setting }\end{array}$ \\
\hline $\begin{array}{l}\text { Distortion of sound or } \\
\text { noisy hearing aid }\end{array}$ & $\begin{array}{l}\text { 1. Battery weak } \\
\text { 2. Contacts dirty or broken } \\
\text { 3. Cord broken } \\
\text { 4. Poor connection between } \\
\text { hearing aid and earmold } \\
\text { 5. Volume control } \\
\text { 6. Microphone opening } \\
\text { dirty or covered } \\
\text { 7. Earmold or in-the-ear } \\
\text { opening plugged } \\
\text { 8. Moisture in earmold } \\
\text { and/or tubing } \\
\text { 9. Tubing collapsed or } \\
\text { twisted }\end{array}$ & $\begin{array}{l}\text { 1. Replace battery } \\
\text { 2. Clean or replace } \\
\text { 3. Replace } \\
\text { 4. Check connections and } \\
\text { aid: make adjustments } \\
\text { 5. Check volume control } \\
\text { setting } \\
\text { 6. Remove dirt from micro- } \\
\text { phone; be sure micro- } \\
\text { phone is left uncovered } \\
\text { 7. Remove wax or dirt with } \\
\text { wax loop remover: wash } \\
\text { earmold if needed } \\
\text { 8. Dry earmold and tubing } \\
\text { well } \\
\text { 9. Untwist and open tubing }\end{array}$ \\
\hline
\end{tabular}




\begin{tabular}{|c|c|c|}
\hline $\begin{array}{l}\text { Intermittent sound } \\
\text { (hearing aid goes on and } \\
\text { off) }\end{array}$ & $\begin{array}{l}\text { 1. Battery almost dead } \\
\text { 2. Bad volume suitch } \\
\text { 3. Moisture in tubing }\end{array}$ & $\begin{array}{l}\text { 1. Put in new battery } \\
\text { 2. Take to a hearing aid } \\
\text { dispenser for repair } \\
\text { 3. Dry tubing (forced air } \\
\text { earmold cleaner) }\end{array}$ \\
\hline $\begin{array}{l}\text { Feedback } \\
\text { (whistling noise) }\end{array}$ & $\begin{array}{l}\text { 1. Earmold not completely } \\
\text { inserted } \\
\text { 2. Earmold is too small } \\
\text { 3. Tubing between aid and } \\
\text { mold loose. broken. cracked } \\
\text { 4. Volume control turned } \\
\text { too high } \\
\text { 5. Internal feedback inside } \\
\text { aid due to defect in aid }\end{array}$ & $\begin{array}{l}\text { 1. Make sure earmold fits } \\
\text { 2. Fit new mold } \\
\text { 3. Check tubing and } \\
\text { replace if necessary } \\
\text { 4. Turn volume down (but } \\
\text { not below its normal } \\
\text { setting) } \\
\text { 5. Check with hearing aid } \\
\text { dispenser }\end{array}$ \\
\hline
\end{tabular}

Wayner. 1990 


\section{EXERCISE}

1. What three types of information can be derived from an audiogram regarding a person's hearing loss?

2. List four kinds of hearing aids.

3. Fill in the correct solutions for a "dead" hearing aid in which there is no sound.

\section{Causes}

Solutions

1. Battery dead

2. Plugs (in cord type)

3. Earmold or tubing plugged

4. Moisture in tubing

5. Controls:
a. on-off switch
b. selector
c. volume

6. Disconnected. twisted. or kinked tubing

7. Cord broken

8. Battery + or - reversed 


\section{ANSWERS}

1. What three types of information can be derived from an audiogram regarding a person's hearing loss?

An audiogram show's the type of hearing loss (conductive. sensorineural, or mixed). the degree of hearing loss (ranging from minimal to profound), and the pattem of hearing loss (how' much hearing loss exists at different frequencies).

2. List four kinds of hearing aids.

- Behind-the-ear hearing aid

- In-the-ear hearing aid

- Canal hearing aid

- Body hearing aid

3. Fill in the blank with the correct solutions for a "dead" hearing aid in which there is no sound.

\section{Causes}

1. Battery dead

2. Plugs (in cord type)

3. Earmold or tubing plugged

4. Moisture in tubing

5. Controls:

a. on-off switch

b. selector

c. volume

6. Disconnected, tuisted, or kinked tubing

7. Cord broken

8. Battery + or - reversed
Solutions

1. Replace battery

2. Clean or replace cord

3. Clean

4. Remove moisture with forced air earmold cleaner

5. Check controls:
a. Make sure it is "on"
b. Switch to " $M$ " (microphone)
c. Turn to appropriate setting 6. Push tubing firmly onto aid. straighten tubing
7. Replace cord
8. Make sure + and - are correctly placed




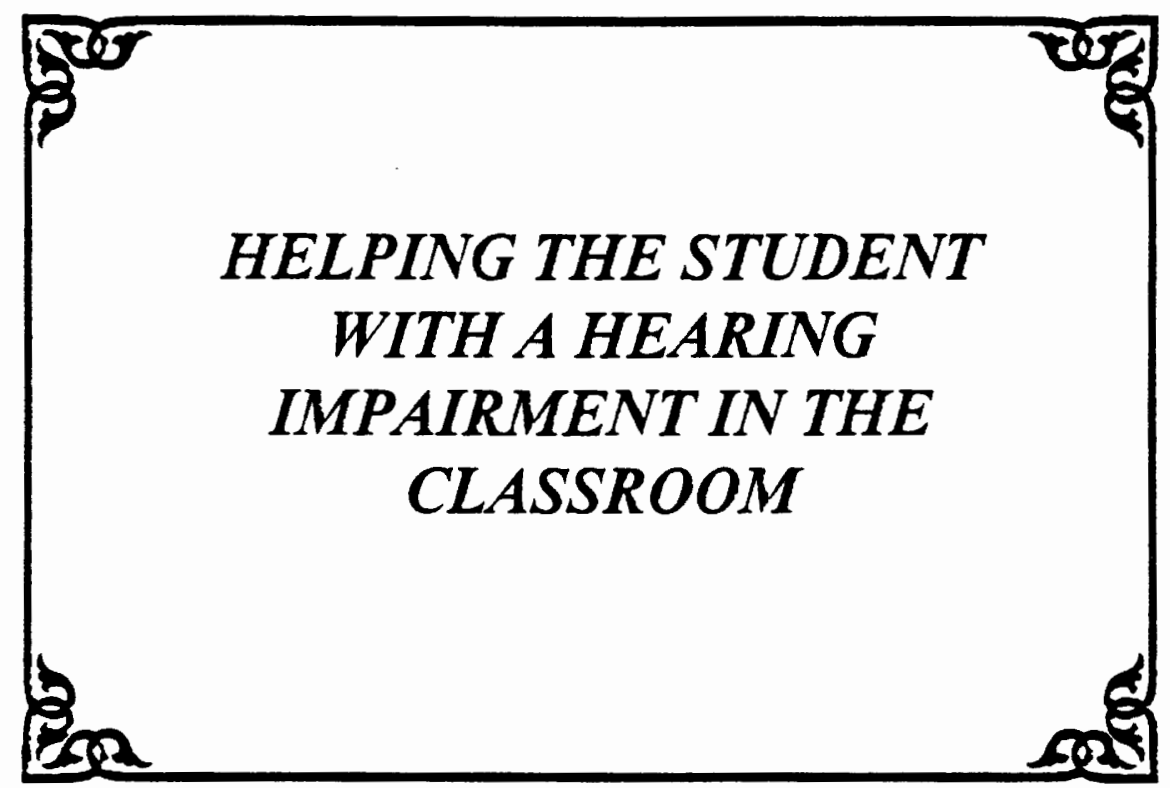




\section{CONCERNS OF THE REGULAR EDUCATION TEACHER}

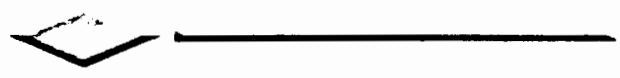

There are many questions that arise when teachers are presented with having to integrate a child who has a hearing impairment into their classroom. Three common concerns are addressed below:

1. Can regular classroom teachers communicate with the hearing-impaired pupil?

Roeser and Downs (1981) explain that most children with hearing impairments who are mainstreamed into regular classrooms have enough residual hearing and expressive language skills to understand speech and to speak intelligibly. However, many children with profound hearing losses do not hav'e the skills needed to understand and use spoken communication. Regular classroom teachers can supplement their communication efforts with these children by using an interpreter or tutor. Training in speechreading (lipreading) may also be provided.

2. Will a child with a hearing impairment distupt the regular class?

Care should be taken during the Indivualized Education Plan (IEP) meetings to determine proper placement of a child with a hearing impairment. In the appropriate setting. a child should not cause disruption. Proper planning by the teacher can also assure that integration of a child with a hearing impairment is not disruptive to the regular classroom schedules or activities.

3. Will children with normal hearing socially accept the child who has a hearing impairment?

It is important that the teacher display a positive attitude about hearingimpairments and a child displaying difficulties in this area. This attitude will be a model for the other children in the class. Presentations about hearing loss and its effects on speech. language and behavior can be given to the classroom to increase acceptance. Learning sign language, listening to hearing aids and testing each other's hearing are examples of planned experiences that can have positive effects on the attitudes of the class.

Roeser \& Downs. 1981 


\section{IDEAS FOR HELPING STUDENTS WITH HEARING IMPAIRMENTS IN THE CLASSROOM}

1. Establish a positive attitude about having children with hearing impairments in your classroom. You are a model for the students in your class.

- Remember that all children are individuals. Just like all children. a child with a hearing impairment has her own strengths and weaknesses.

- Provide a buddy system. Buddies can sit next to these students and alert them of any instructions given by the teacher. The buddies can also provide assistance by sharing lecture notes.

- Help the class to understand hearing and hearing loss by having a specialist discuss the ear, hearing . hearing loss. aids. noise. etc. . .

- Encourage hearing-impaired children to participate in class activities.

- Answer questions conceming the child and hearing impairments in matter-offact terms. This will demonstrate your comfort and help other students to accept their peer.

- Be willing to use different methods to optimize a hard of hearing child's ability to learn.

2. Position children with hearing impairments in the most favorable seat for a given activity.

- Noise interferes with listening and understanding. Attempt to remove these children from noise sources such as fans and heating șstems. cafeterias. music rooms. gy'ms and other classrooms as well as play ground noises that may' interfere with the child's ability to hear speech.

- Place them close to the area where you instruct. but not so close that they must look up to obtain information.

- Place them at a distance of between three and six feet from the speaker. so that distance will not be a variable in speechreading and listening.

- Place these children with their better ear toward the speaker.

- Avoid moving around while you talk.

3. Make sure you have the attention of children who present hearing difficulties and are clearly visible to them before you start to speak.

- Stand in clear light and face the children. This will make your lip movements. facial expressions and gestures easier to see.

- Do not obscure your mouth or chew food while speaking.

- Never have light behind you when giving instructions. 
- When speaking directly to these children. kneel down to their level and look into their eves. Eyes can relay much of a message.

4. Speak naturally and use gestures and facial expressions as much as possible. A child with a hearing impairment may rely heavily on visual cues to aid understanding.

- Speak in a low' intensity. Do not shout. This distorts the sound of your voice.

- Speak clearly' and slowly. Don't clip word endings or mumble. and don't overarticulate your w'ords.

- Do not exaggerate mouth movements. facial expressions or gestures.

- Do slow down your rate.

- Stress key words and natural pauses.

- Rephrase what you have said when you think the child has misunderstood.

- Introduce new topics clearly with short sentences.

- Be sure the child understands when questions are being asked.

5. Provide written instructions and summaries to help the child keep in touch with lesson content. Visual aids should be used whenever possible.

- Place a simple lesson outline on the board

- Give written tests whenever possible

- Write key words and phrases on the board as the lesson progresses.

- Write homework assignments on the board. Have children confirm homework assignments at the end of the day.

6. Remember that concentrated looking and listening is tiring. Children that have hearing impairments must constantly put together what they hear and see to make guesses about what is being communicated. This takes a lot of energ!:

- Schedule breaks and less directed activities so that these children will get a chance to recuperate.

7. Because these children may have speech and language problems. encourage speech and language development and reinforce communicative efforts.

- Set up situations in which the child can communicate with others.

- Do not pretend to understand the child or interrupt to make corrections.

- If you have difficulty understanding the child. ask her to repeat.

- Do not call attention to the child's speech errors in the classroom. Record and share them with the speech pathologist.

- Realize that the child may have limited vocabulary and syntax. both receptively and expressively. Her failure to understand may be related to this as well as the hearing problem. 
8. The amplification used by children with hearing impairments is essential to their success.

- Check hearing aids daily to ensure that they are functioning.

- Encourage these children to tell you if the aid is not working properly. then consult the appropriate support personnel.

9. The parents of the child may be anxious about his/her ability to cope in class. When reporting to the parents, be sure to discuss the child's strengths as well as weaknesses.

10. Use support personnel such as speech-language pathologists. school pychologists. or educational audiologists as consultants.

- They are available to provide special services to these children.

- They can answer questions that you. the students or the parents may have.

- They can help to increase your knowledge and give suggestions about how to alter your classroom to suit children with hearing problems.

Davis. 1977

Wayner. 1990

Roeser \& Downs, 1981

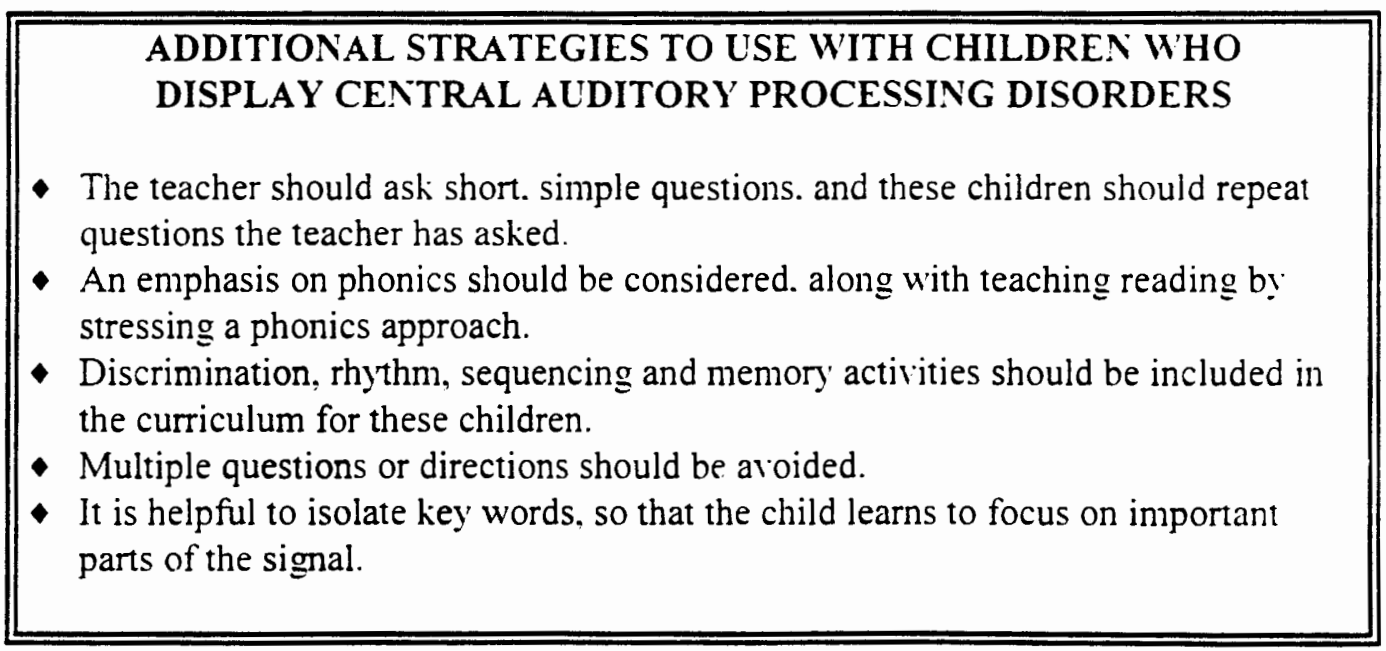




\section{GESTURES AND FACIAL EXPRESSIONS THAT CAN BE USED IN THE CLASSROOM}

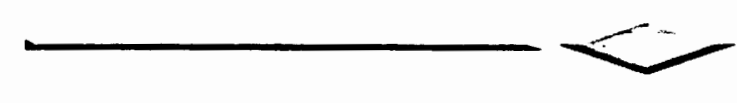

\section{GESTURE}

1. Pain raised to another person

2. Forefinger held to closed lips

3. Wiggling crooked index finger

4. Both palnis open. extended forward and lified 2 or 3 times

5. Right hand. paln open. swept forward in a pushing away. gesture

6. Both arms extended. open palms turned up

7. Thumb and 2 fingers of right hand rubbed together with hand extended

8. Hands together pains facing in

9. Look displeased and shake head

10. Point to child with questioning look on face

11. Point to child with worried. questioning look on face

\section{INTERPRETATION}

Stop

Quiet

Come here

Stand up. get up

Take it away. go away. I don't want it

Help me

Hand it to me

Please

That is not acceptable

What are you doing?

What is wrong? 


\section{EXERCISE}

1. Will a child who has a hearing impairment disrupt the regular class?

2. List four things you can do to make sure you have the attention of a child with a hearing impairment.

3. List four ways you can encourage speech and language development and reinforce communicative effort. 


\section{ANSWERS}

1. How can classroom teachers help children with normal hearing socially accept the child who has a hearing impairment?

It is important that the teacher display' a positive attitude about a hearing impairment and the child displaying difficulties in this area. This attitude will be a model for the other children in the class. Presentations about hearing loss and its effects on speech, language and behavior can be given to the classroom to increase their acceptance. Learning sign language, listening to hearing aids and testing each other's hearing are examples of planned experiences that can have positive effects on the attitudes of the class.

2. List four things you can do to make sure you have the attention of a child with a hearing impairment.

- Stand in clear light and face the children. This will make your lip movements, facial expressions and gestures easier to see.

- Do not obscure your mouth or chew food while speaking.

- Never have light behind you when giving instructions.

- When speaking directly to these children, kneel down to their level and look into their eyes. Eyes can relay much of a message.

3. List four way's you can encourage speech and language development and reinforce communicative effort.

- Set up situations in which the child can communicate with others.

- Do not pretend to understand the child or interrupt to make corrections.

- If you have difficulty understanding the child, ask her to repeat.

- Do not call attention to the child's speech errors in the classroom. Record and share them with the speech pathologist.

- Realize that the child may have limited vocabulary and syntax, both receptively and expressively. Her failure to understand may be related to this as well as the hearing problem. 


\section{REFERENCES}

Fisher L. (1976). Fisher's auditory problems checklist. Bemidji. MN: Life Products.

Roeser, R. \& Dow'ns, M. (1981). Auditory disorders in school children: The law identification and remediation. New York: Thieme-Stratton. Inc.

Willeford, J. \& Burleigh. J. (1985). Handbook of central auditory processing disorders in children. Orlando. FL: Grune \& Stratton. Inc.

Wayner. D. (1990). The hearing aid handbonk: User's guide for children. Washington, D.C.: Gallaudet University Press.

Flexer. C. (1994). Facilitating hearing and listening in voung children. San Diego, CA: Singular Publishing Group. Inc.

Davis. J. (Ed.). (1977). Qur forgotten children: Hard-of-hearing pupils in the schools. Minneapolis. MN: Audio Visual Library Service, University of Minnesota.

Simko. C. (1986). Wired for sound: An advanced student workbook on hearing and hearing aids. Washington. D.C.: Gallaudet University Press. 
APPENDIX E

POST TEST 
Subject \#:

Please circle the option which best answers the question.

1. Which behavior is recommended if you want the attention of a child with a hearing impairment?
a. stand in a dimly lit area so as to raise curiosity
b. obscure your mouth or chew food while speaking
c. be sure a light source is behind you when giving instructions
d. kneel down to their level and look into their eyes
e. none of these are recommended behaviors

2. A breakdown in communication between two people can cause:
a. anticipation
b. deliberation
c. frustration
d. palpitation

3. Which is not one of the types of information that can be derived regarding a person's hearing loss from an audiogram?
a. percent of hearing loss
b. pattern of hearing loss
c. degree of hearing loss
d. type of hearing loss

4. The most common cause of otitis media (i.e., middle-ear infections) is:
a. eustachian tube dysfunction
b. swimming
c. childhood illnesses such as measles or chicken pox
d. inheritance from one of the parents

5. Displaying a positive attitude about hearing impairment and the child displaying difficulties can be a model for others in the class.
a. True
b. False 
6. Which of the following is not a behavior that may indicate hearing loss?
a. high achievement levels in classroom studies
b. watches and concentrates on teacher's lips
c. talks too loudly or softly
d. shows strain in trying to hear

7. The term used to describe the whistling sound sometimes made by hearing aids is:
a. distortion
b. gain
c. feedback
d. output
e. amplification

8. The proper name for the part of the outer ear we see on the side of the head is:
a. ossicle
b. cochlea
c. pinna
d. lobe

9. Which hearing aid component is responsible for converting the amplified electrical signal back into sound and delivering it to the child's ear?
a. microphone
b. amplifier
c. receiver
d. earmold
e. speaker

10. A cochlear-implant can be expected to provide which of the following benefits for a school-aged child?
a. improved speech understanding over the phone
b. improved speech understanding in the classroom
c. improved ability to utilize speech cues such as voicing and fundamental frequency
d. improved ability to read and spell

11. What happens when sounds hit the eardrum?
a. The eardrum reverberates.
b. The eardrum vibrates.
c. The listener experiences pain.
d. All of the above 
12. When should a teacher use the Fisher's Auditory Problems Checklist?
a. at the beginning of the school year on all students
b. mid-year on all suspected hearing-impaired students
c. prior to promotion to the next grade for all students
d. as soon as hearing loss behaviors are observed

13. Which of the following is an expected benefit of wearing a hearing aid?
a. Hearing will be corrected in much the same way that glasses correct vision.
b. Speech will be louder and easier to understand.
c. The incidence of ear infections will decrease.
d. All of these are expected benefits.
e. Only $a$ or b can be expected to occur.

14. The middle ear contains which three bones?
a. hammer, chisel, and bridle
b. hammer, anvil, and bridle
c. ratchet, anvil, and stirrup
d. hammer, anvil, and stirrup

15. The nerve endings responsible for hearing are found in which part of the ear?
a. the outer ear
b. the middle ear
c. the inner ear

16. Which of the following is not a type of hearing aid?
a. in front-of-the ear hearing aid
b. in-the-ear hearing aid
c. body hearing aid
d. none of these are hearing aid types
e. all of these are hearing aid types

17. What are the three types of hearing loss?
a. conductive, convective, sensorineural
b. mixed, convective, sensorineural
c. mixed, conductive, sensorineural
d. mixed, conductive, sensorineural 
18. An in-the-canal style hearing aid is not appropriate for a school-aged child because
a. their ear is still growing
b. this type provided limited high-frequency response due to feedback problems
c. limits in using direct audio input devices with this style
d. all of these may be valid reasons
e. some of these are valid reasons

19. Which of the following is not an indication of a hearing loss?
a. noncompliant behavior
b. prefers loud volumes
c. talks softly
d. turns one side of head toward speaker
e. these are all indications of a hearing loss

20. A hearing aid may whistle if
a. the earmold fits loosely
b. the battery is weak or dead
c. the child speaks loudly
d. the hearing aid is old
e. the earmold is dirty or partially filled with wax

21. What type of information can be derived from an audiogram regarding a child's hearing loss?
a. the type and degree of loss
b. the percentage of words that a person can understand
c. whether surgery can be used to correct the hearing problem
d. the most appropriate classroom placement for a hearing-impaired child.

22. Which of the following is not a way to encourage speech and language development or reinforce communicative effort?
a. Set up situations in which the child can communicate with others.
b. Pretend to understand the child, but do not interrupt to make corrections.
c. Do not call attention to the child's speech errors in the classroom.
d. If you have difficulty understanding the child, ask her to repeat. 
23. Which of the following situations could result from a dead or weak battery?
a. no sound from the hearing aid at all
b. intermittent sound from the hearing aid
c. poor sound quality from the hearing aid
d. all of these
e. only a or b

24. The leading cause of acquired sensorineural hearing loss in children is
a. ear infections
b. meningitis
c. allergies
d. inheritance

25. Which of the following is not a problem that a student with a hearing impairment might encounter in school?
a. reading a spelling
b. trouble hearing films in school
c. difficulty in understanding directions
d. trouble watching films in school 
APPENDIX F

SELF-DIRECTED INSERVICE PROGRAM FEEDBACK 


\section{Self-Directed Inservice Program Feedback}

1. Do you feel better informed about hearing loss and how to meet the classroom needs of students with hearing impairments? Please explain.

2. Do you like the self-directed inservice approach to staff development? Why or why not?

3. What additional topics on hearing impairment do you wish had been included?

4. Additional comments: 
APPENDIX G

ARTICLE READY BY THE CONTOL GROUP 

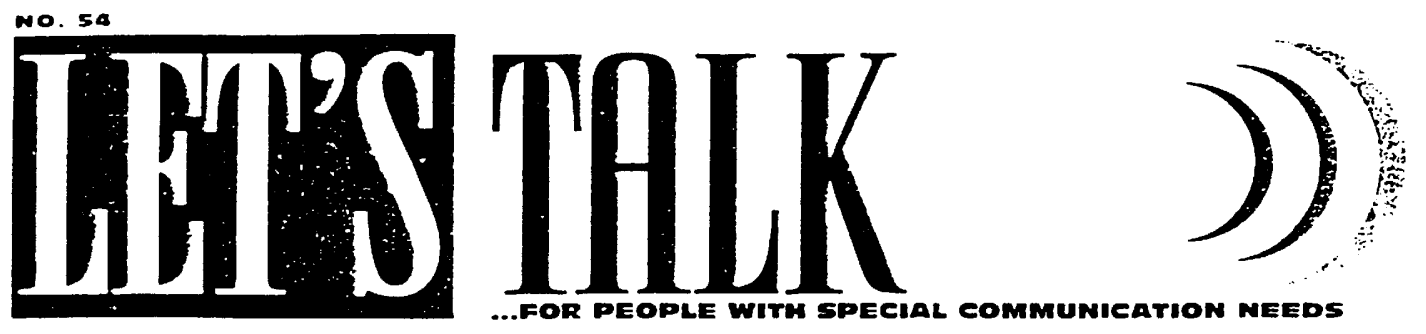

\section{Deaf Eulture}

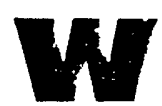

hat does it means to be a Deaf person in a hearing world? Many members of the Deaf communty vien their deafness as a unique characteristic that makes them part of a community that shares a common experience, tradition, history, and language. People who are Deaf share an idennty, not a disease or a disability.

This point of view was summarized well by one Deaf man who said, "l am not hearins-impaired. The w'ord 'impaired' implies a nrohler, and I, as well as many other Deat people. do not percerve being Deaf as a problem. Deaf adults...would rather be vinwed as a minority group with their cur. language and culture."

\section{American Sign Language (AsL)}

in the Linited States and Canada, this lan. Fuage 1s Amerkin Sign

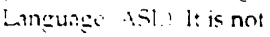

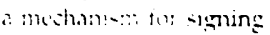

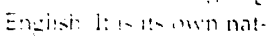
wrally castrm: lanEuage usce by a specific culture ans posiessing

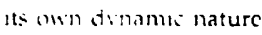
ASL can express any thonght of todu!

As with other lan Suages, ASI criates new simbols as netrled, and older simbuts p.2* out of common ksige Mcarung

just as other cultumal groups sueh as Mispanies and asians share a collective heritoge, people who are

\section{Deaf feel that}

deafmess is part of their cultural

heritoge. changes deponding on

how the s!minol si deliveni: A simple "no" is distenguishet frm an enptutic " $n$ " by the sperd and fone with whion the sign is mase.

When spuaters of dirierent languages want to communicatc, the usc interpreters

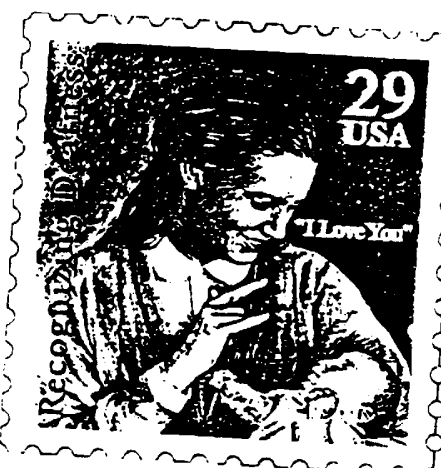

and are not considered to be disabled. When English speakers and ASL users want to communicate, they also need interpreters and neither party in the communication should be viewed as disabled.

\section{eultume and Ethnicity}

Not ondy language but also the shared experience of deamess give members of the Deai commuruti an exclusive linh to each other likened to leelings of ethnicin: lust as other cultural groups such as Hispanics and Asians share a collectuve heritage, people who are Deaf feel that deamess is part of their cultural heritage. Thes take prise in that heritage and have a passionate sense of cultural unity and fellowship.

This unity captured the attention of the nation in March 1988. In a weeh-long pritest that reminded many of past studient

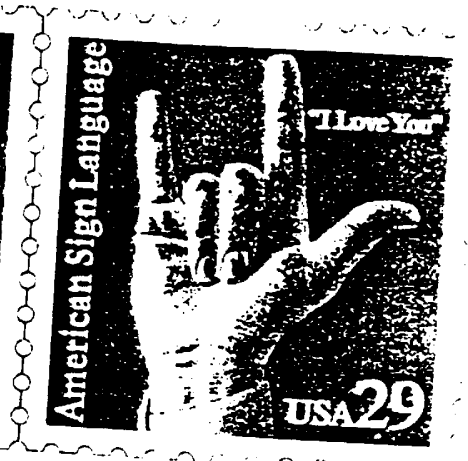

and civil rights struggles, the students at Gallaudet University in Miashington, $D C$ objected to the appointment of a new hearing president who did not know' sign ianguage or the Deaf culture. Classes were boycotted, entrances barricaded, the administration buildung harred by bihe chains, and students marchung to the Capitol to press their demands were jouled by busloads of supporters trom nearby states The new president a wel! as the thairman

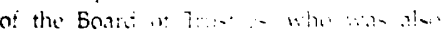
hearmy, wert forid: :

\section{Technology and Education}

Such patemolism lout tw surprose when some in the Deaf communts indicate that they do not wish to have intart hearing Nen technologies. such as cochleat implants, developed to mohe hearing pormsible, may be rejected as unnecessary and unwelcome. The implication of the technology is that a patholing! "xists and needs to be cured. However, if one twilieves, as many Deaf advocates do, that nothung is broken, nothing nerds to to fixent. In iacl. teclinological interientuon can even bs viewed as a strong and direct statement against Deaf culture. 


\section{APPENDIX H}

\section{SELF-DIRECTED INSERVICE PROGRAM FEEDBACK RESPONSES}




\section{SELF DIRECTED INSERVICE PROGRAM FEEDBACK RESPONSES}

\begin{tabular}{|c|c|}
\hline Subject & Questions and Responses \\
\hline$\# 1$ & $\begin{array}{l}\text { 1. Do you feel better informed about hearing loss and how to meet the classroom needs } \\
\text { of students with hearing impairments? } \\
\text { Yes. Excellent reminders/suggestions. } \\
\text { 2. Do you like the self-directed inservice approach to staff development? Why or why } \\
\text { not? } \\
\text { Yes. It's appropriate and very useful in an environment of limited resources } \\
\text { and scant training opportunities. It's not as good as hands on experience with } \\
\text { an instructor and students with hearing impairment. } \\
\text { 3. What additional topics on hearing impairment do you wish had been included? } \\
\text { None. } \\
\text { 4. Additional comments: } \\
\text { Thanks for the opportunity. }\end{array}$ \\
\hline$\# 2$ & $\begin{array}{l}\text { 1. Do you feel better informed about hearing loss and how to meet the classroom } \\
\text { needs of students with hearing impairments? } \\
\text { Yes. The book was informative and gave me lots to work with when working } \\
\text { with a hearing impaired child. } \\
\text { 2. Do you like the self-directed inservice approach to staff development? Why or why } \\
\text { not? } \\
\text { Yes. I learned the material easier with this format. } \\
\text { 3. What additional topics on hearing impairment do you wish had been included? } \\
\text { I felt there was enough information to digest. } \\
\text { 4. Additional comments: } \\
\text { Good experience and worthwhile use of my time. }\end{array}$ \\
\hline$\# 3$ & $\begin{array}{l}\text { 1. Do you feel better informed about hearing loss and how to meet the classroom needs } \\
\text { of students with hearing impairments? } \\
\text { Yes. I felt the ideas presented were easy to understand and well organized. } \\
\text { As a reference I find the information helpful. } \\
\text { 2. Do you like the self-directed inservice approach to staff development? Why or why } \\
\text { not? } \\
\text { Yes. I liked being able to recheck information and read at my own pace. } \\
\text { 3. What additional topics on hearing impairment do you wish had been included? } \\
\text { Perhaps some behavior management practices that have been successful with } \\
\text { other experienced teachers. } \\
\text { 4. Additional comments: } \\
\text { No response was given. }\end{array}$ \\
\hline
\end{tabular}




\begin{tabular}{|c|c|}
\hline Subject & Questions and Responses \\
\hline$\# 4$ & $\begin{array}{l}\text { 1. Do you feel better informed about hearing loss and how to meet the classroom needs } \\
\text { of students with hearing impairments? } \\
\text { Yes, thanks for the info. } \\
\text { 2. Do you like the self-directed inservice approach to staff development? Why or why } \\
\text { not? } \\
\text { Easy to ready but no immediate access to a person for clarification. Could } \\
\text { have been able to take my time (not one week) to read, review, and perhaps } \\
\text { discuss with other staff. } \\
\text { 3. What additional topics on hearing impairment do you wish had been included? } \\
\text { Possible causes } \\
\text { 4. Additional comments: } \\
\text { Thanks for the opportunity to participate. Wished it would have occurred } \\
\text { earlier in the month. }\end{array}$ \\
\hline$\# 5$ & $\begin{array}{l}\text { 1. Do you feel better informed about hearing loss and how to meet the classroom needs } \\
\text { of students with hearing impairments? } \\
\text { Yes, although much of the info. seems "common sense." The checklists are } \\
\text { helpful. } \\
\text { 2. Do you like the self-directed inservice approach to staff development? Why or why } \\
\text { not? } \\
\text { Very much--it doesn't waste my time! } \\
\text { 3. What additional topics on hearing impairment do you wish had been included? } \\
\text { No response was given. } \\
\text { 4. Additional comments: } \\
\text { Some of the text item info. was not given in my booklet--but you probably } \\
\text { know that! }\end{array}$ \\
\hline$\# 6$ & $\begin{array}{l}\text { 1. Do you feel better informed about hearing loss and how to meet the classroom needs } \\
\text { of students with hearing impairments? } \\
\text { Yes, most information was helpful and interesting. } \\
\text { 2. Do you like the self-directed inservice approach to staff development? Why or why } \\
\text { not? } \\
\text { Yes and no. It depends upon the subject matter and if assistance is available. } \\
\text { 3. What additional topics on hearing impairment do you wish had been included? } \\
\text { The different causes of hearing loss needed to be included. } \\
\text { 4. Additional comments: } \\
\text { Take out the answers, most teachers will look back through info. to find the correct } \\
\text { answer. At times it was repetitive to the point it was insulting to the professional } \\
\text { reading it. This would be extreme helpful for rural teachers, i.e., Eastern Oregon. }\end{array}$ \\
\hline
\end{tabular}




\begin{tabular}{|c|c|}
\hline Subject & Questions and Responses \\
\hline$\# 7$ & $\begin{array}{l}\text { 1. Do you feel better informed about hearing loss and how to meet the classroom needs } \\
\text { of students with hearing impairments? } \\
\text { Yes. The booklet was able to give me more information about how to work } \\
\text { with this type of student. } \\
\text { 2. Do you like the self-directed inservice approach to staff development? Why or why } \\
\text { not? Yes. I could work at this on my own time and pace. } \\
\text { 3. What additional topics on hearing impairment do you wish had been included? } \\
\text { At this time cannot think of any new or more information. } \\
\text { 4. Additional comments: } \\
\text { None. }\end{array}$ \\
\hline$\# 8$ & $\begin{array}{l}\text { 1. Do you feel better informed about hearing loss and how to meet the classroom needs } \\
\text { of students with hearing impairments? } \\
\text { Yes. Your information covered the technical and the practical. } \\
\text { 2. Do you like the self-directed inservice approach to staff development? Why or why } \\
\text { not? } \\
\text { Yes. It was easy to review the material as needed. } \\
\text { 3. What additional topics on hearing impairment do you wish had been included? } \\
\text { None. } \\
\text { 4. Additional comments: } \\
\text { No response was given. }\end{array}$ \\
\hline$\# 9$ & $\begin{array}{l}\text { 1. Do you feel better informed about hearing loss and how to meet the classroom needs } \\
\text { of students with hearing impairments? } \\
\text { Yes. I though the checklists for possible identification, visual cues that can be } \\
\text { used were very helpful. } \\
\text { 2. Do you like the self-directed inservice approach to staff development? Why or why } \\
\text { not? } \\
\text { Yes. Could go through the material at my leisure (basically--1 week) and in a } \\
\text { more relaxed manner. } \\
\text { 3. What additional topics on hearing impairment do you wish had been included? } \\
\text { It was well covered. Perhaps more on speech related problems. } \\
\text { 4. Additional comments: } \\
\text { Very helpful. }\end{array}$ \\
\hline
\end{tabular}




\begin{tabular}{|l|l|}
\hline Subject & Questions and Responses \\
\hline$\# 10$ & $\begin{array}{l}\text { 1. Do you feel better informed about hearing loss and how to meet the classroom needs } \\
\text { of students with hearing impairments? } \\
\text { Yes. Practical, specific medical and instructional information can be used } \\
\text { from the provided booklet. }\end{array}$ \\
$\begin{array}{l}\text { 2. Do you like the self-directed inservice approach to staff development? Why or why } \\
\text { not? } \quad \text { Yes, if I would have taken more time to really read the material. }\end{array}$ \\
$\begin{array}{l}\text { 3. What additional topics on hearing impairment do you wish had been included? } \\
\text { Future potential devices as a result of technology that would facilitate hearing. } \\
\text { Additional comments: } \\
\text { None. }\end{array}$ \\
\hline
\end{tabular}

